Prepared in cooperation with Colorado Water Conservation Board and the Bureau of Reclamation

\title{
Installation of a Groundwater Monitoring-Well Network on the East Side of the Uncompahgre River in the Lower Gunnison River Basin, Colorado, 2012
}

Data Series 923

U.S. Department of the Interior U.S. Geological Survey

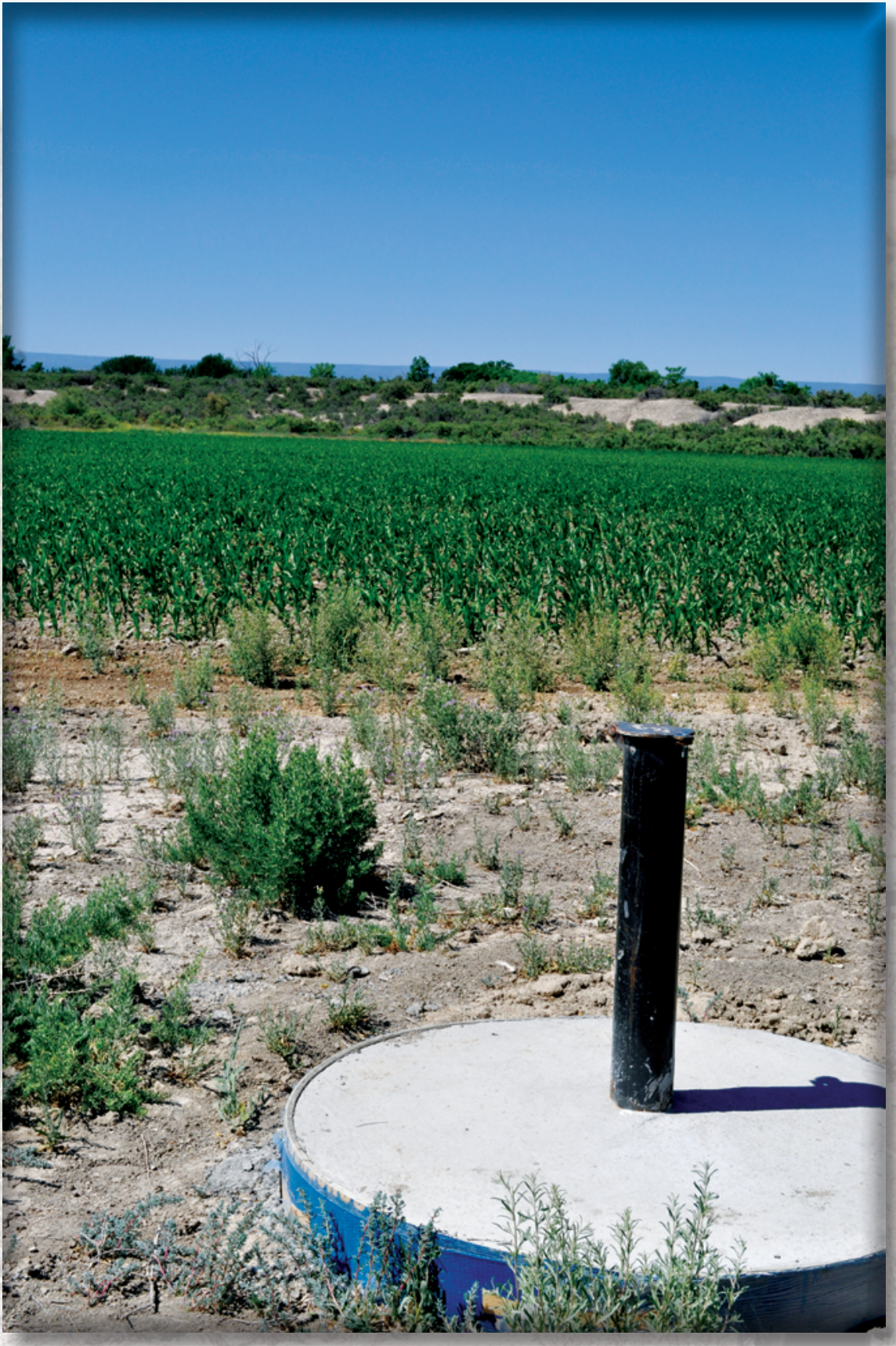


Cover. Monitoring well adjacent to corn field, lower Gunnison River Basin, Montrose County, Colorado, June 2013.

Photo by Judith Thomas, U.S. Geological Survey. 


\section{Installation of a Groundwater Monitoring- Well Network on the East Side of the Uncompahgre River in the Lower Gunnison River Basin, Colorado, 2012}

By Judith C. Thomas and L. Rick Arnold

Prepared in cooperation with Colorado Water Conservation Board and the

Bureau of Reclamation

Data Series 923 


\title{
U.S. Department of the Interior SALLY JEWELL, Secretary
}

\section{U.S. Geological Survey \\ Suzette M. Kimball, Acting Director}

\author{
U.S. Geological Survey, Reston, Virginia: 2015
}

For more information on the USGS - the Federal source for science about the Earth, its natural and living resources, natural hazards, and the environment—visit http://www.usgs.gov or call 1-888-ASK-USGS.

For an overview of USGS information products, including maps, imagery, and publications, visit http://www.usgs.gov/pubprod/.

Any use of trade, firm, or product names is for descriptive purposes only and does not imply endorsement by the U.S. Government.

Although this information product, for the most part, is in the public domain, it also may contain copyrighted materials as noted in the text. Permission to reproduce copyrighted items must be secured from the copyright owner.

Suggested citation:

Thomas, J.C., and Arnold, L.R., 2015, Installation of a groundwater monitoring-well network on the east side of the Uncompahgre River in the Lower Gunnison River Basin, Colorado, 2012: U.S. Geological Survey Data Series 923, 29 p., http://dx.doi.org/10.3133/ds923.

ISSN 2327-638X (online) 


\section{Contents}

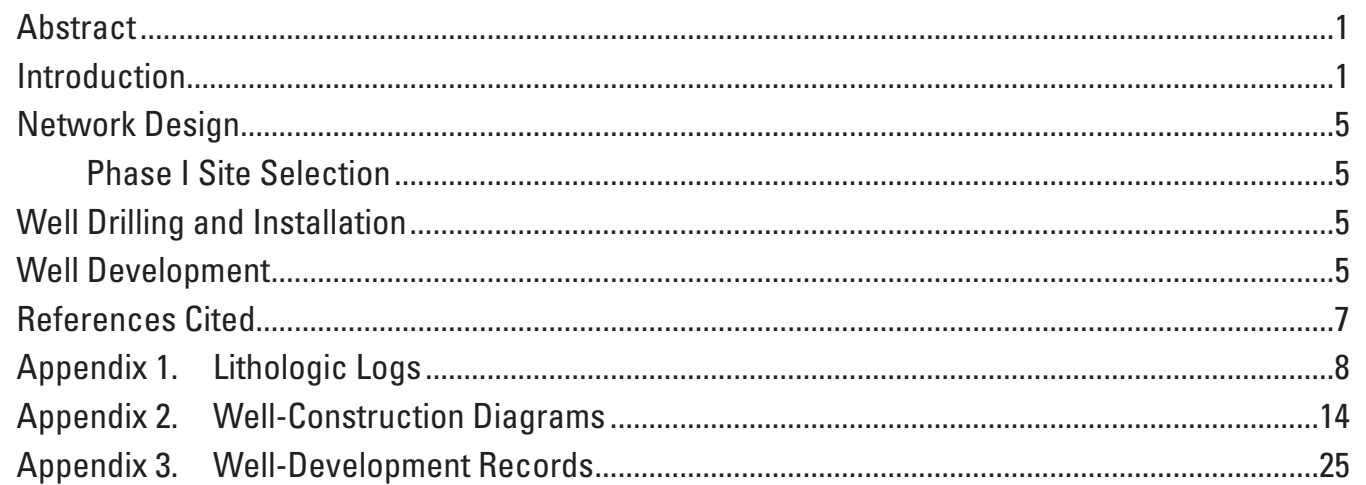

\section{Figures}

1. Location of study area on the east side of the Uncompahgre River Basin, Colorado .....2

2. Location of the 30 equal-area polygons and the randomly selected sites considered for drilling within each (primary, secondary, and tertiary sites), east side of the Uncompahgre River Basin, Colorado..

3. Location of monitoring wells installed and dry holes drilled during October and November of calendar year 2012, east side of the Uncompahgre River Basin, Colorado

\section{Table}

1. Summary of groundwater monitoring well locations, construction, and depth to water 


\section{Conversion Factors}

\begin{tabular}{|c|c|c|}
\hline Multiply & By & To obtain \\
\hline \multicolumn{3}{|c|}{ Length } \\
\hline inch (in.) & 2.54 & centimeter $(\mathrm{cm})$ \\
\hline foot $(\mathrm{ft})$ & 0.3048 & meter (m) \\
\hline mile (mi) & 1.609 & kilometer (km) \\
\hline millimeter $(\mathrm{mm})$ & 0.0393701 & inch (in.) \\
\hline \multicolumn{3}{|c|}{ Area } \\
\hline square mile $\left(\mathrm{mi}^{2}\right)$ & .590 & square kilometer $\left(\mathrm{km}^{2}\right)$ \\
\hline \multicolumn{3}{|c|}{ Volume } \\
\hline gallon (gal) & .785 & liter $(\mathrm{L})$ \\
\hline \multicolumn{3}{|c|}{ Flow rate } \\
\hline gallon per minute (gal/min) & .06309 & liter per second $(\mathrm{L} / \mathrm{s})$ \\
\hline \multicolumn{3}{|c|}{ Hydraulic conductivity } \\
\hline foot per day (ft/d) & 0.3048 & meter per day $(\mathrm{m} / \mathrm{d})$ \\
\hline
\end{tabular}

Temperature in degrees Celsius $\left({ }^{\circ} \mathrm{C}\right)$ may be converted to degrees Fahrenheit $\left({ }^{\circ} \mathrm{F}\right)$ as follows:

${ }^{\circ} \mathrm{F}=\left(1.8 \mathrm{x}^{\circ} \mathrm{C}\right)+32$

Vertical coordinate information was referenced to North American Vertical Datum of 1988 (NAVD 88).

Horizontal coordinate information was referenced to North American Datum of 1983 (NAD 83).

Specific conductance was given in microsiemens per centimeter at 25 degrees Celsius ( $\mu \mathrm{S} / \mathrm{cm}$ at $\left.25^{\circ} \mathrm{C}\right)$. 


\title{
Installation of a Groundwater Monitoring-Well Network on the East Side of the Uncompahgre River in the Lower Gunnison River Basin, Colorado, 2012
}

\author{
By Judith C. Thomas and L. Rick Arnold
}

\section{Abstract}

The east side of the Uncompahgre River Basin has been a known contributor of dissolved selenium to recipient streams. Discharge of groundwater containing dissolved selenium contributes to surface-water selenium concentrations and loads; however, the groundwater system on the east side of the Uncompahgre River Basin is not well characterized. The U.S. Geological Survey, in cooperation with the Colorado Water Conservation Board and the Bureau of Reclamation, has established a groundwater-monitoring network on the east side of the Uncompahgre River Basin. Ten monitoring wells were installed during October and November 2012. This report presents location data, lithologic logs, well-construction diagrams, and well-development information. Understanding the groundwater system will provide managers with an additional metric for evaluating the effectiveness of salinity and selenium control projects.

\section{Introduction}

The east side of the Uncompahgre River Basin has been a known contributor of dissolved selenium to recipient streams. The U.S. Fish and Wildlife Service and the U.S. Geological Survey (USGS), as part of National Irrigation Water Quality Program (NIQWP), found that dissolved selenium concentrations were elevated for both groundwater and river systems in irrigated parts of the Uncompahgre River Basin in the lower Gunnison River Basin (Butler and others, 1996). As a result, selenium produced by irrigated areas was thought to be detrimentally affecting native Colorado River Basin fish species. The Colorado Department of Public Health and Environment (CDPHE) have since adopted standards for selenium in the lower Gunnison River Basin. Many rivers and streams of the east side of the Uncompahgre River Basin are selenium impaired for cold water fisheries on the Colorado's 303(d) list (Colorado Department of Public Health and Environment, 1998), and concentrations have exceeded the 85 th percentile chronic aquatic-life standard for dissolved selenium (4.6 micrograms per liter) as established by the State of Colorado (Butler and Leib, 2002; Thomas and others, 2007). Despite the implementation of control projects (designed to limit the mobilization of selenium) in the region, there are indications that selenium loads may be increasing (Moore, 2011).

Perennial streamflow on the east side of the Uncompahgre River Basin is supported by seasonal tributary inflow, irrigation-return flows, and shallow groundwater discharge from areas underlain by selenium-bearing shale. Previous work in the basin (Bureau of Reclamation, 1982) supports a conceptual model of water-table (unconfined) groundwater conditions present beneath irrigated areas and in proximity to streams. Discharge of groundwater containing dissolved selenium contributes to surface-water selenium concentrations and loads; however, the groundwater system on the east side of the Uncompahgre River Basin is not well characterized. Additional information such as depth to water, extent and thickness of saturation, hydraulic conductivity, and groundwater selenium concentrations are needed to understand characteristics of the groundwater system. Understanding the groundwater system will provide managers with an additional metric for evaluating the effectiveness of salinity and selenium control projects. Coupled with current surfacewater monitoring, groundwater monitoring will provide a more complete understanding of all the factors involved in achieving success in control projects. The USGS, in cooperation with Colorado Water Conservation Board and the Bureau of Reclamation has established a groundwatermonitoring network on the east side of the Uncompahgre River Basin. This report describes the first phase of the implementation of a monitoring-well network designed to characterize the groundwater quality on the east side of the Uncompahgre River Basin.

The purpose of this report is to document the design and installation of a groundwater-monitoring network on the east side of the Uncompahgre River Basin in Colorado (fig. 1). This report documents network design, well drilling and installation of 10 sites, and well development. 


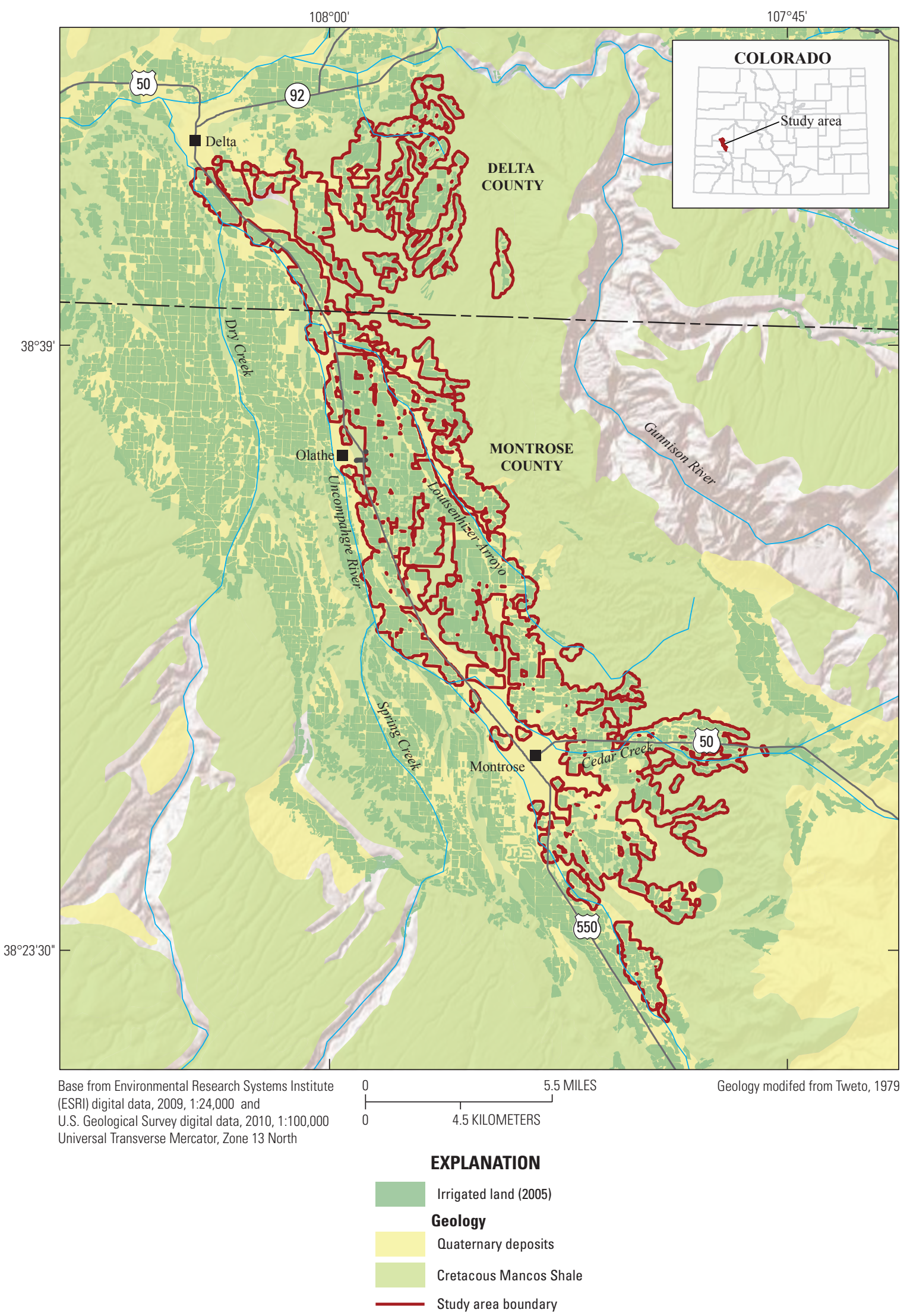

Figure 1. Location of study area on the east side of the Uncompahgre River Basin, Colorado. 


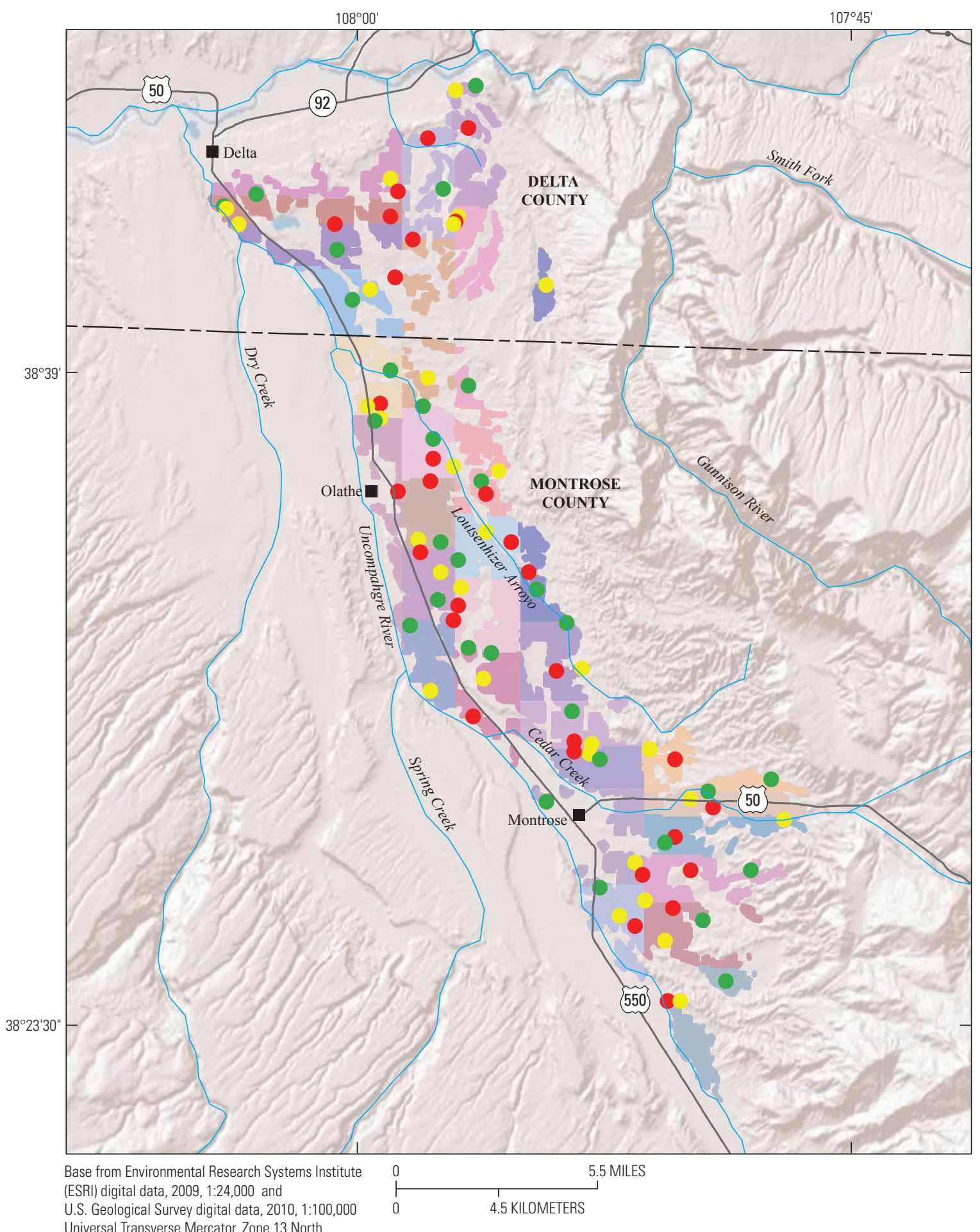

Universal Transverse Mercator, Zone 13 North

\section{EXPLANATION}

\section{Equal area polygons}

Polygons 1 through 30

(different color for each polygon)

\section{Randomly selected sites}

Primary site

Secondary site

- Tertiary site

Figure 2. Location of the 30 equal-area polygons and the randomly selected sites considered for drilling within each (primary, secondary, and tertiary sites), east side of the Uncompahgre River Basin, Colorado. 


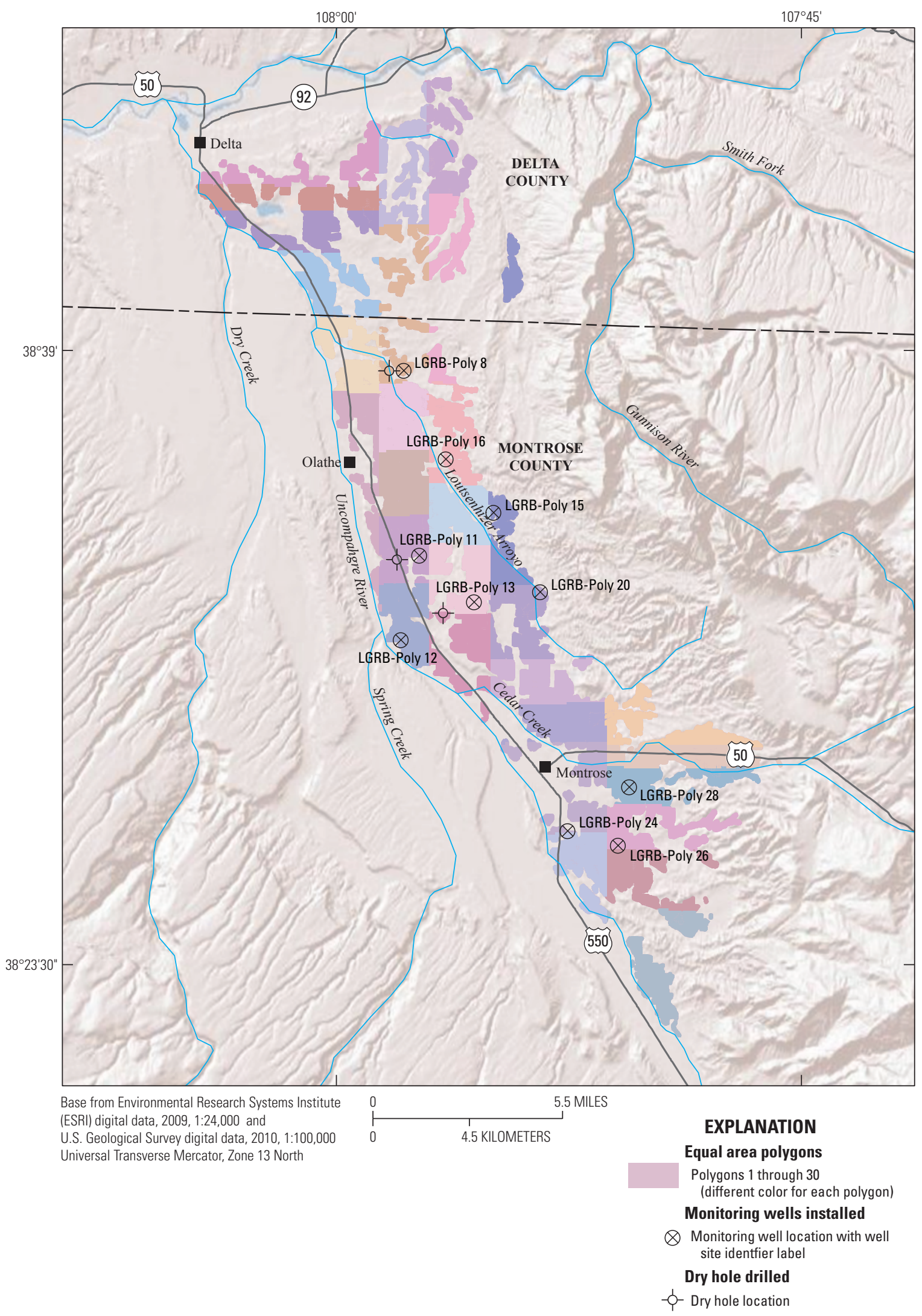

Figure 3. Location of monitoring wells installed and dry holes drilled during October and November of calendar year 2012, east side of the Uncompahgre River Basin, Colorado. 


\section{Network Design}

In order to better understand the shallow groundwater system, a 30-well uniform randomized groundwater-monitoring network was developed to provide a statistically robust groundwater-monitoring network design. The study area is on the east side of the Uncompahgre River Basin (fig. 1) where irrigation is occurring within the Bureau of Reclamation's Uncompahgre Project. The Uncompahgre Project is in west-central Colorado and includes lands that surround the town of Montrose and extend 34 miles along both sides of the Uncompahgre River to Delta, Colorado (Bureau of Reclamation, 2014). The project is a series of dams, canals, laterals, and drains and draws water from the Uncompahgre and Gunnison Rivers for irrigation of project land. Network design was based on information from Alley (1993) and has been used by the USGS National Water Quality Assessment program in national investigations. The network design was created using a computerized technique (Scott, 1990) that generates a random distribution of potential groundwater-sampling sites. The study area was determined by intersecting digital maps of irrigated land within the Uncompahgre Project. The resulting study area was used as input to the program developed by Scott (1990) for site selection. The random site-selection process divided the study area into 30 equal-area polygons and then generated three potential groundwater-monitoring sites within each polygon: a primary, secondary, and tertiary site (fig. 2). When establishing sites, the primary site was considered first, followed by the secondary and tertiary sites.

\section{Phase I Site Selection}

Ten of the 30 randomly determined sites were installed in October and November of calendar year 2012 (fig. 3). These 10 sites were selected from among the first primary sites where landowners were contacted and agreed to participate in the study.

\section{Well Drilling and Installation}

Monitoring-well drilling and installation occurred during October and November 2012 (table 1). Drilling services were provided by the Bureau of Reclamation Drilling Operations Group of Pleasant Grove, Utah. Borehole drilling and well installation was overseen by a USGS hydrologist, who documented daily drilling operations, logged and packaged geologic materials encountered while drilling, and prepared well-construction reports in accordance with USGS Guidelines (http://ga.water.usgs.gov/gwqa/gwpd.7.4.16.html, accessed June 25, 2012) and State of Colorado drilling regulations (http://water.state.co.us/groundwater/BOE/Pages/BOERules. aspx, accessed December 31, 2013). USGS staff were responsible for coordination of drilling services and obtaining permits required by the State of Colorado for well drilling.

Boreholes for monitoring wells were drilled with a truckmounted CME75 drilling rig. Boreholes were advanced with 4.25-inch (in) inside diameter (ID) hollow-stem augers, and split-spoon samples of geologic materials were collected as needed to properly identify formation intervals for well installation. Lithologic logs were developed on the basis of visual inspection of split spoon samples and auger cuttings (Appendix 1). Lithologic descriptions are based on the Wentworth classification system (Wentworth, 1922). Of the 13 holes drilled in October and November 2012, 3 were dry, indicating discontinuous groundwater within the study area (fig. 3).

Individual well-construction diagrams are presented in Appendix 2. Wells were constructed using 2-in diameter Schedule 40 polyvinyl chloride (PVC) casing with a locking cap and protective surface casing. Well screens were either 5 or 10 feet (ft) long and installed near the bottom of the saturated thickness. A 2- to 5-ft-long sump was installed below the screen in some of the monitoring wells (where possible). Annular space adjacent to the screened interval was backfilled with a graded sand pack. Annular space above the screened interval was plugged with bentonite, and a concrete well pad was placed at the surface. Other aspects of well construction were in accordance with USGS specifications for waterquality wells (Lapham and others, 1997) and Colorado State regulations (http://water.state.co.us/groundwater/BOE/Pages/ BOERules.aspx, accessed December 31, 2013).

\section{Well Development}

Wells were developed after drilling to remove mud and any foreign material from the well and to help improve the hydraulic connection between the well and aquifer. Well development was completed in May 2013 and was accomplished using a combination of bailing, pumping, and mechanical surging for a maximum of 8 hours or until the produced water was clear and parameters such as turbidity, specific conductance, and $\mathrm{pH}$ were stable. A Waterra Hydrolift 2 inertial pump system was used to develop the wells. Well development information is provided for each well in Appendix 3. 
Table 1. Summary of groundwater monitoring well locations, construction, and depth to water.

[LGRB, lower Gunnison River basin; Poly, polygon number; DDMMSS, degrees, minutes, seconds; stick-up height in feet above land surface; all depths in feet below land surface]

\begin{tabular}{|c|c|c|c|c|c|c|c|c|c|c|c|c|}
\hline $\begin{array}{c}\text { Well } \\
\text { identifier }\end{array}$ & $\begin{array}{c}\text { USGS site } \\
\text { identification } \\
\text { number }\end{array}$ & $\begin{array}{c}\text { Latitude } \\
\text { (DDMMSS) }\end{array}$ & $\begin{array}{l}\text { Longitude } \\
\text { (DDMMSS) }\end{array}$ & $\begin{array}{c}\text { Date } \\
\text { completed }\end{array}$ & $\begin{array}{l}\text { Depth to } \\
\text { water }\end{array}$ & $\begin{array}{l}\text { Stick-up } \\
\text { height }\end{array}$ & $\begin{array}{l}\text { Depth to } \\
\text { top of } \\
\text { screen }\end{array}$ & $\begin{array}{l}\text { Depth to } \\
\text { bottom of } \\
\text { screen }\end{array}$ & $\begin{array}{c}\text { Depth to } \\
\text { top of } \\
\text { annular seal }\end{array}$ & $\begin{array}{l}\text { Depth to } \\
\text { top of sand } \\
\text { pack }\end{array}$ & $\begin{array}{l}\text { Depth to } \\
\text { bottom of } \\
\text { sand pack }\end{array}$ & $\begin{array}{l}\text { Total } \\
\text { well } \\
\text { depth }\end{array}$ \\
\hline $\begin{array}{l}\text { LGRB Poly } 8 \\
\text { (dry hole) }\end{array}$ & -- & 383858 & 1075723 & $10 / 28 / 2012$ & $\begin{array}{l}\text { No completion-dry } \\
\text { hole. Refusal at } \\
34.2 \mathrm{ft}\end{array}$ & & & & & & & \\
\hline LGRB Poly 8 & 383844107572801 & & & $11 / 11 / 2012$ & 11.8 & 2.8 & 15.1 & 20.0 & 1.4 & 14.1 & 21.6 & 24.0 \\
\hline $\begin{array}{l}\text { LGRB Poly } 11 \\
\text { (dry hole) }\end{array}$ & -- & 383408 & 1075645 & $10 / 28 / 2012$ & $\begin{array}{l}\text { No completion-dry } \\
\text { hole. Refusal at } \\
19.2 \mathrm{ft}\end{array}$ & & & & & & & \\
\hline LGRB Poly 11 & 383405107564701 & & & $11 / 10 / 2012$ & 6 & 2.3 & 7.2 & 16.9 & 1.8 & 6.0 & 19.0 & 19.0 \\
\hline LGRB Poly 12 & 383156107571701 & & & $11 / 11 / 2012$ & 9.0 & 1.8 & 11.1 & 16.0 & 1.0 & 5.5 & 19.0 & 19.0 \\
\hline $\begin{array}{l}\text { LGRB Poly } 13 \\
\text { (dry hole) }\end{array}$ & -- & 383245 & 1075516 & $10 / 27 / 2012$ & $\begin{array}{l}\text { No completion-dry } \\
\text { hole. Refusal at } \\
13.2 \mathrm{ft}\end{array}$ & & & & & & & \\
\hline LGRB Poly 13 & 383257107545801 & & & $11 / 10 / 2012$ & 8.2 & 2.6 & 10.1 & 15.0 & 0.5 & 8.5 & 18.0 & 19.0 \\
\hline LGRB Poly 15 & 383513107542601 & & & $10 / 27 / 2012$ & 9.7 & 2.6 & 17.9 & 27.6 & 0.8 & 15.7 & 26.6 & 31.7 \\
\hline LGRB Poly 16 & 383632107560201 & & & $10 / 28 / 2012$ & 21.1 & 2.8 & 24.3 & 34.0 & 1.0 & 21.6 & 36.3 & 39.3 \\
\hline LGRB Poly 20 & 383315107525201 & & & $10 / 26 / 2012$ & 14 & 2.9 & 19.2 & 28.9 & 1.6 & 17.0 & 31.0 & 34.2 \\
\hline LGRB Poly 24 & 382715107514501 & & & $6 / 13 / 2013$ & 14.8 & 3.1 & 17.0 & 21.9 & 0.5 & 15.3 & 24.0 & 27.1 \\
\hline LGRB Poly 26 & 382656107500701 & & & $10 / 25 / 2012$ & 10.4 & 2.5 & 15.0 & 19.9 & 1.0 & 13.1 & 22.0 & 24.4 \\
\hline LGRB Poly 28 & 382824107494801 & & & $10 / 25 / 2012$ & 9.9 & 2.7 & 15.7 & 20.6 & 1.0 & 13.8 & 20.8 & 20.8 \\
\hline
\end{tabular}




\section{References Cited}

Alley, W.M., ed., 1993, Regional ground-water quality: New York, Van Nostrand Reinhold, 634 p.

Bureau of Reclamation, 1982, Lower Gunnison Basin Unit feasibility report-Appendix B hydrosalinity: Bureau of Reclamation, Colorado River Water Quality Improvement Program.

Bureau of Reclamation, 2014, Uncompahgre project: Bureau of Reclamation, accessed August 25, 2014 at http://www.usbr.gov/projects/Project.jsp?proj Name $=$ Uncompahgre + Project.

Butler, D.L., and Leib, K.J., 2002, Characterization of selenium in the lower Gunnison River Basin, Colorado, 1988-2000: U.S. Geological Survey Water-Resources Investigations Report 02-4151, 26 p.

Butler, D.L., Wright, W.G., Stewart, K.C., Osmundson, B.C., Krueger, R.P., and Crabtree, D.W., 1996, Detailed study of selenium and other constituents in water, bottom sediment, soil, alfalfa, and biota associated with irrigation drainage in the Uncompahgre Project Area and in the Grand Valley, west-central Colorado, 1991-93: U.S. Geological Survey Water-Resources Investigations Report 96-4138, 136 p.

Geological Society of America, 1995, Rock-color chart with genuine Munsell color chips: Grand Rapids, Mich., Munsell Color, 10 p. [8th printing]
Lapham, W.W., Franceska, D.W., and Koterba, M.T., 1997, Guidelines and standard procedures for studies of groundwater quality-Selection and installation of wells, and supporting documentation: U.S. Geological Survey WaterResources Investigations Report 96-4233, 110 p.

Moore, J.L., 2011, Characterization of salinity and selenium loading and land-use change in Montrose Arroyo, Western Colorado, from 1992 to 2010: U.S. Geological Survey Scientific Investigations Report 2011-5106, 23 p., at http://pubs.usgs.gov/sir/2011/5106/.

Scott, J.C., 1990, Computerized stratified random siteselection approaches for design of a ground-water-quality sampling network: U.S. Geological Survey Water-Resources Investigations Report 90-4101, 109 p.

Thomas, J.C., Leib, K.J., and Mayo, J.W., 2007, Analysis of dissolved selenium loading for selected sites in the lower Gunnison River Basin, Colorado, 1978-2005: U.S. Geological Survey Scientific Investigations Report 2007-5287, 25 p., at http://pubs.usgs.gov/sir/2007/5287/.

Tweto, Ogden, comp.,1979, Geologic map of Colorado: U.S. Geological Survey State Geologic Map, scale 1:500,000 (reprinted).

Wentworth, C.K., 1922, A scale of grade and class terms for clastic sediments: Journal of Geology, v. 30, p. 377-392. 


\title{
Appendix 1. Lithologic Logs
}

\author{
LGRB Poly 8 (Dry hole) \\ Date well completed: 10/28/2012

\section{Log prepared by L.R. Arnold}

[Depth intervals in feet below land surface; ft, feet; HCl, hydrochloric acid, LGRB, lower Gunnison River Basin; Poly, polygon number]

\begin{tabular}{|c|c|c|}
\hline Depth & Sample type & Description' \\
\hline $0-22.4$ & surface and core & $\begin{array}{l}\text { Weathered Mancos Shale-Sand and clay, pale yellowish brown }(10 \mathrm{YR} 6 / 2) \text { to moderate yellow- } \\
\text { ish brown }(10 \mathrm{YR} 5 / 4) \text {, sand portion is very fine grained with trace fine-medium grains, clay } \\
\text { content increases with depth, little silt, lenses of fine sand with some silt and trace clay, well } \\
\text { sorted, weakly fissile, angular-subangular, medium dense-dense, dry-damp, trace calcium } \\
\text { carbonate mottling, reacts to HCl. }\end{array}$ \\
\hline $22.4-31.2$ & core & $\begin{array}{l}\text { Weathered Mancos Shale-Clay, moderate yellowish brown }(10 \mathrm{YR} 5 / 4) \text {, little very fine sand } \\
\text { and trace fine--medium sand, hard-very hard, moist with occasional thin lenses of wet, trace } \\
\text { calcium carbonate mottling, reacts to } \mathrm{HCl} \text {, drilling refusal at } 34.2 \mathrm{ft} \text {. }\end{array}$ \\
\hline
\end{tabular}

'Grain size based on the Wentworth classification system (Wentworth, 1922). Proportions defined using the following terms: "trace" (0-10 percent), "little" (10-20 percent), "some" (20-35 percent), and "and" (35-50 percent). Color codes (for example, 10YR6/2) refer to the Munsell color system (Geological Society of America, 1995).

\section{LGRB Poly 8}

Date well completed: 11/11/2012

\section{Log prepared by L.R. Arnold}

[Depth intervals in feet below land surface; mm, millimeters; ft, feet; $\mathrm{HCl}$, hydrochloric acid, LGRB, lower Gunnison River Basin; Poly, polygon number]

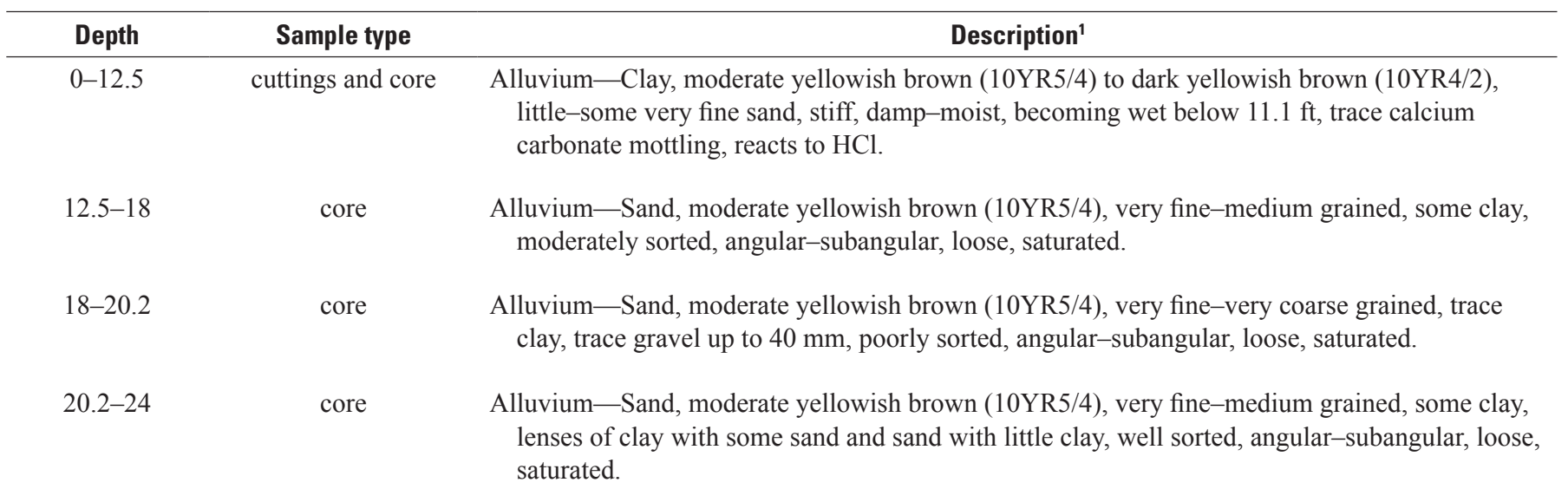

${ }^{1}$ Grain size based on the Wentworth classification system (Wentworth, 1922). Proportions defined using the following terms: "trace" (0-10 percent), "little" (10-20 percent), "some" (20-35 percent), and "and" (35-50 percent). Color codes (for example, 10YR6/2) refer to the Munsell color system (Geological Society of America, 1995). 


\section{LGRB Poly 11 (Dry hole)}

Date well completed: 10/28/2012

\section{Log prepared by L.R. Arnold}

[Depth intervals in feet below land surface; ft, feet; HCl, hydrochloric acid, LGRB, lower Gunnison River Basin; Poly, polygon number]

\begin{tabular}{|c|c|c|}
\hline Depth & Sample type & Description $^{1}$ \\
\hline $0-4.4$ & surface and core & $\begin{array}{l}\text { Fill - Clay, mottled pale yellowish brown }(10 \mathrm{YR} 6 / 2) \text { to dark yellowish brown }(10 \mathrm{YR} 4 / 2) \text {, some } \\
\text { very fine sand and trace fine-medium sand, soft, damp-moist, some organic material, reacts to } \\
\mathrm{HCl} \text {. }\end{array}$ \\
\hline $4.4-19.2$ & core & $\begin{array}{l}\text { Weathered Mancos Shale-Clay, mottled moderate yellowish brown (10YR5/4), dark yellowish } \\
\text { orange (10YR6/6), and medium dark gray (N4), becoming dark gray (N3) below about } 15 \mathrm{ft} \text {, } \\
\text { little very fine sand and trace fine-medium sand, occasional lenses of fine sand with some } \\
\text { clay, fissile, hard-very hard, dry-damp, trace small gypsum crystals in partings, trace iron } \\
\text { staining, reacts to } \mathrm{HCl} \text {, drilling refusal at } 19.2 \mathrm{ft} \text {. }\end{array}$ \\
\hline
\end{tabular}

${ }^{1}$ Grain size based on the Wentworth classification system (Wentworth, 1922). Proportions defined using the following terms: "trace" (0-10 percent), "little" (10-20 percent), "some" (20-35 percent), and "and" (35-50 percent). Color codes (for example, 10YR6/2) refer to the Munsell color system (Geological Society of America, 1995).

\section{LGRB Poly 11}

Date well completed: 11/10/2012

\section{Log prepared by L.R. Arnold}

[Depth intervals in feet below land surface; ft, feet; HCl, hydrochloric acid, LGRB, lower Gunnison River Basin; Poly, polygon number]

\begin{tabular}{|c|c|c|}
\hline Depth & Sample type & Description' ${ }^{1}$ \\
\hline $0-16.7$ & surface and core & $\begin{array}{l}\text { Alluvium - Clay and sand, dusky yellow (5Y6/4) to moderate yellowish brown }(10 \mathrm{YR} 5 / 4) \text {, sand } \\
\text { portion is very fine grained with trace fine-medium grains, soft, damp-moist, becoming wet- } \\
\text { saturated below about } 6 \mathrm{ft} \text {, trace calcium carbonate mottling, some organic material } 0-1 \mathrm{ft} \text {, } \\
\text { reacts to } \mathrm{HCl} \text {. }\end{array}$ \\
\hline $16.7-19$ & core & $\begin{array}{l}\text { Weathered Mancos Shale-Clay, light olive gray }(5 \mathrm{Y} 5 / 2) \text { to olive gray }(5 \mathrm{Y} 3 / 2) \text {, trace very fine } \\
\text { sand, nonfissile, hard, dry-damp, trace calcium carbonate mottling, small gypsum crystals, and } \\
\text { iron staining, reacts to } \mathrm{HCl} \text {. }\end{array}$ \\
\hline
\end{tabular}

'Grain size based on the Wentworth classification system (Wentworth, 1922). Proportions defined using the following terms: "trace" (0-10 percent), "little" (10-20 percent), "some" (20-35 percent), and "and" (35-50 percent). Color codes (for example, 10YR6/2) refer to the Munsell color system (Geological Society of America, 1995).

\section{LGRB Poly 12}

Date well completed: 11/11/2012

\section{Log prepared by L.R. Arnold}

[Depth intervals in feet below land surface; mm, millimeters; ft, feet; HCl, hydrochloric acid, LGRB, lower Gunnison River Basin; Poly, polygon number]

\begin{tabular}{ccc}
\hline Depth & Sample type & \multicolumn{1}{c}{ Description $^{1}$} \\
\hline $0-5.3$ & surface and core & $\begin{array}{c}\text { Alluvium-Sand, dark yellowish brown (10YR4/2), very fine grained with trace fine-medium } \\
\text { grains, trace clay with lenses of little clay, well sorted, loose, moist, some organic material } \\
0-1 \mathrm{ft} .\end{array}$ \\
& cuttings and core & $\begin{array}{c}\text { Alluvium-Gravel and cobbles, grayish brown (5YR3/2), cobbles up to 100 mm in size, some } \\
\text { very fine-very coarse sand, trace clay, poorly sorted, dense, angular-rounded, saturated. }\end{array}$
\end{tabular}

\footnotetext{
${ }^{1}$ Grain size based on the Wentworth classification system (Wentworth, 1922). Proportions defined using the following terms: "trace" (0-10 percent), "little" (10-20 percent), "some" (20-35 percent), and "and" (35-50 percent). Color codes (for example, 10YR6/2) refer to the Munsell color system (Geological Society of America, 1995).
} 


\section{LGRB Poly 13 (Dry hole)}

Date well completed: 10/27/2012

\section{Log prepared by L.R. Arnold}

[Depth intervals in feet below land surface; $\mathrm{ft}$, feet; HCl, hydrochloric acid, LGRB, lower Gunnison River Basin; Poly, polygon number]

\begin{tabular}{|c|c|c|}
\hline Depth & Sample type & Description $^{1}$ \\
\hline $0-1$ & surface & $\begin{array}{l}\text { Surface soil-Sand, grayish orange (10YR7/4), very fine grained with trace fine-medium grains, } \\
\text { some clay, well sorted, subangular, loose, dry-damp, reacts to } \mathrm{HCl} \text {. }\end{array}$ \\
\hline $1-13.2$ & cuttings and core & $\begin{array}{l}\text { Weathered Mancos Shale-Clay, grayish orange }(10 \mathrm{YR} 7 / 4) \text { to pale yellowish brown }(10 \mathrm{YR} 6 / 2) \text {, } \\
\text { becoming olive gray }(5 \mathrm{Y} 4 / 1) \text { below about } 8 \mathrm{ft} \text {, some very fine sand and trace fine-medium } \\
\text { sand, occasional lenses of fine sand with some clay, fissile, hard-very hard, dry-damp, trace } \\
\text { small gypsum crystals in partings, trace iron staining, reacts to } \mathrm{HCl} \text {, drilling refusal at } 13.2 \mathrm{ft} \text {. }\end{array}$ \\
\hline
\end{tabular}

${ }^{1}$ Grain size based on the Wentworth classification system (Wentworth, 1922). Proportions defined using the following terms: "trace" (0-10 percent), "little" (10-20 percent), "some" (20-35 percent), and "and" (35-50 percent). Color codes (for example, 10YR6/2) refer to the Munsell color system (Geological Society of America, 1995).

\section{LGRB Poly 13}

\section{Date well completed: 11/10/2012}

\section{Log prepared by L.R. Arnold}

[Depth intervals in feet below land surface; mm, millimeters; ft, feet; HCl, hydrochloric acid, LGRB, lower Gunnison River Basin; Poly, polygon number]

\begin{tabular}{|c|c|c|}
\hline Depth & Sample type & Description $^{1}$ \\
\hline $0-10$ & surface and core & $\begin{array}{l}\text { Alluvium-Sand, grayish orange (10YR7/4) to dark yellowish brown }(10 \mathrm{YR} 6 / 6) \text {, very fine } \\
\text { grained with trace fine-medium grains, some clay, well sorted, angular-subangular, loose-- } \\
\text { medium dense, moist, becoming wet-saturated below } 7.5 \mathrm{ft} \text {, trace calcium carbonate mottling } \\
\text { and iron staining, reacts to } \mathrm{HCl} \text {. }\end{array}$ \\
\hline $10-14.5$ & core & $\begin{array}{l}\text { Alluvium-Sand, grayish orange (10YR7/4) to dark yellowish brown }(10 \mathrm{YR} 6 / 6) \text {, very fine- } \\
\text { very coarse grained, some clay, trace gravel up to } 40 \mathrm{~mm} \text { diameter, poorly sorted, angular- } \\
\text { subangular, loose-medium dense, saturated, trace calcium carbonate mottling, iron staining, } \\
\text { and fossil fragments, reacts to } \mathrm{HCl} \text {. }\end{array}$ \\
\hline $14.5-19$ & core & $\begin{array}{l}\text { Weathered Mancos Shale-Clay, light olive brown }(5 \mathrm{Y} 5 / 6) \text { to olive gray }(5 \mathrm{Y} 3 / 2) \text {, trace very fine } \\
\text { sand, fissile, hard, damp-moist, some small gypsum crystals in partings, trace iron staining, } \\
\text { reacts to } \mathrm{HCl} \text {. }\end{array}$ \\
\hline
\end{tabular}

${ }^{1}$ Grain size based on the Wentworth classification system (Wentworth, 1922). Proportions defined using the following terms: "trace" (0-10 percent), "little" (10-20 percent), "some” (20-35 percent), and "and" (35-50 percent). Color codes (for example, 10YR6/2) refer to the Munsell color system (Geological Society of America, 1995).

\section{LGRB Poly 15}

Date well completed: 10/27/2012

\section{Log prepared by L.R. Arnold}

[Depth intervals in feet below land surface; ft, feet; HCl, hydrochloric acid, LGRB, lower Gunnison River Basin; Poly, polygon number]

\begin{tabular}{|c|c|c|}
\hline Depth & Sample type & Description $^{1}$ \\
\hline $0-34.2$ & surface and core & $\begin{array}{l}\text { Alluvium-Sand, grayish orange (10YR7/4) to pale yellowish brown }(10 \mathrm{YR} 6 / 2) \text {, very fine } \\
\text { grained with trace fine-medium grains, some clay, lens of fine-coarse sand with trace gravel } \\
\text { from } 29.0-29.8 \mathrm{ft} \text {, well sorted, angular-subangular, loose, dry-damp, becoming wet-saturated } \\
\text { below } 18 \mathrm{ft} \text {, some organic material } 0-2 \mathrm{ft} \text {, reacts to } \mathrm{HCl} \text {. }\end{array}$ \\
\hline
\end{tabular}

'Grain size based on the Wentworth classification system (Wentworth, 1922). Proportions defined using the following terms: "trace" (0-10 percent), "little" (10-20 percent), "some” (20-35 percent), and "and" (35-50 percent). Color codes (for example, 10YR6/2) refer to the Munsell color system (Geological Society of America, 1995). 


\section{LGRB Poly 16}

Date well completed: 10/28/2012

Log prepared by L.R. Arnold

[Depth intervals in feet below land surface; mm, millimeters; ft, feet; HCl, hydrochloric acid, LGRB, lower Gunnison River Basin; Poly, polygon number]

\begin{tabular}{|c|c|c|}
\hline Depth & Sample type & Description $^{1}$ \\
\hline $0-25.8$ & surface and core & $\begin{array}{l}\text { Alluvium-Clay, pale yellowish brown (10YR6/2), some very fine sand and trace fine-medium } \\
\text { sand, soft, damp-moist, becoming wet below } 23.3 \mathrm{ft} \text {, some organic material } 0-3 \mathrm{ft} \text {, reacts to } \\
\mathrm{HCl} \text {. }\end{array}$ \\
\hline $25.8-31.9$ & core & $\begin{array}{l}\text { Alluvium-Sand, pale yellowish brown (10YR6/2), very fine grained with trace fine-medium } \\
\text { grains and lenses of little-some medium-coarse sand, some clay, well sorted, subangular, } \\
\text { loose, saturated, reacts to } \mathrm{HCl} \text {. }\end{array}$ \\
\hline $31.9-34.8$ & core & $\begin{array}{l}\text { Alluvium-Sand, moderate yellowish brown }(10 \mathrm{YR} 5 / 4) \text {, very fine-very coarse grained, trace } \\
\text { clay with thin }(0.1 \mathrm{ft}) \text { lenses of some clay, trace gravel up to } 14 \mathrm{~mm} \text { diameter, poorly sorted, } \\
\text { loose, angular-subangular, saturated, mild reaction to } \mathrm{HCl} \text {. }\end{array}$ \\
\hline $34.8-39.3$ & core & $\begin{array}{l}\text { Alluvium-Sand, pale yellowish brown }(10 \mathrm{YR} 6 / 2) \text {, very fine grained with little fine-medium } \\
\text { grains and lenses of little-some medium-coarse sand, well sorted, subangular, loose, saturated, } \\
\text { reacts to } \mathrm{HCl} \text {. }\end{array}$ \\
\hline
\end{tabular}

${ }^{1}$ Grain size based on the Wentworth classification system (Wentworth, 1922). Proportions defined using the following terms: "trace" (0-10 percent), "little" (10-20 percent), "some" (20-35 percent), and "and" (35-50 percent). Color codes (for example, 10YR6/2) refer to the Munsell color system (Geological Society of America, 1995).

\section{LGRB Poly 20}

Date well completed: 10/26/2012

\section{Log prepared by L.R. Arnold}

[Depth intervals in feet below land surface; ft, feet; HCl, hydrochloric acid, LGRB, lower Gunnison River Basin; Poly, polygon number]

\begin{tabular}{|c|c|c|}
\hline Depth & Sample type & Description ${ }^{1}$ \\
\hline $0-29.1$ & surface and core & $\begin{array}{l}\text { Alluvium-Clay, dark yellowish brown }(10 \mathrm{YR} 4 / 2) \text {, some very fine sand and trace fine-medium } \\
\text { sand, soft, damp-moist, becoming wet below } 14 \mathrm{ft} \text {, some calcium carbonate mottling, trace } \\
\text { iron staining, some organic material } 0-2 \mathrm{ft} \text {, reacts to } \mathrm{HCl} \text {. }\end{array}$ \\
\hline $29.1-39.3$ & core & $\begin{array}{l}\text { Weathered Mancos Shale-Clay, mottled light olive gray }(5 \mathrm{Y} 5 / 2) \text {, light olive brown }(5 \mathrm{Y} 5 / 6) \text {, } \\
\text { and olive gray }(5 \mathrm{Y} 3 / 2) \text {, trace very fine sand with lenses containing some very fine sand and } \\
\text { trace fine-medium sand, fissile, stiff-very stiff, damp-moist, some small gypsum crystals in } \\
\text { partings, some iron staining, reacts to HCl. }\end{array}$ \\
\hline
\end{tabular}

${ }^{1}$ Grain size based on the Wentworth classification system (Wentworth, 1922). Proportions defined using the following terms: "trace" (0-10 percent), "little" (10-20 percent), "some" (20-35 percent), and "and" (35-50 percent). Color codes (for example, 10YR6/2) refer to the Munsell color system (Geological Society of America, 1995). 


\section{LGRB Poly 24}

Date well completed: 10/24/2012

\section{Log prepared by L.R. Arnold}

[Depth intervals in feet below land surface; mm, millimeters; ft, feet; HCl, hydrochloric acid, LGRB, lower Gunnison River Basin; Poly, polygon number]

\begin{tabular}{|c|c|c|}
\hline Depth & Sample type & Description ${ }^{1}$ \\
\hline $0-1.5$ & surface & $\begin{array}{l}\text { Surface soil-Sand, moderate yellowish brown (10YR5/4) to dark yellowish brown (10YR4/2), } \\
\text { fine-coarse grained, some clay, little gravel up to } 38 \mathrm{~mm} \text { diameter, poorly sorted, angular- } \\
\text { subangular, loose, dry, some organic material. }\end{array}$ \\
\hline $1.5-20.5$ & cuttings and core & $\begin{array}{l}\text { Alluvium-Clay, moderate yellowish brown }(10 \mathrm{YR} 5 / 4) \text { to dark yellowish brown }(10 \mathrm{YR} 4 / 2) \text {, } \\
\text { some very fine sand and trace fine-medium sand, soft, damp, becoming wet-saturated below } \\
16.8 \mathrm{ft} \text {, trace calcium carbonate mottling, carbon specks, and iron staining, reacts to } \mathrm{HCl} \text {. }\end{array}$ \\
\hline $20.5-22.5$ & core & $\begin{array}{l}\text { Alluvium-Sand, pale yellowish brown }(10 \mathrm{YR} 6 / 2) \text { to moderate yellowish brown (10YR5/4), } \\
\text { fine-coarse grained, some gravel up to } 33 \mathrm{~mm} \text { from } 21.6-22.5 \mathrm{ft} \text {, little clay, poorly sorted, } \\
\text { angular-subrounded, loose-medium dense, saturated, alluvium. }\end{array}$ \\
\hline $22.5-29.1$ & core & $\begin{array}{l}\text { Weathered Mancos Shale-Clay, mottled dusky yellow (5Y6/4), light olive gray }(5 \mathrm{Y} 5 / 2) \text {, and } \\
\text { medium dark gray (N4), becoming more dark gray (N4) with depth, fissile, occasional thin } \\
\text { (up to } 5 \mathrm{~mm} \text { ) lenses of some very fine-fine sand, very stiff-hard, damp, trace small gypsum } \\
\text { crystals and iron staining, reacts to } \mathrm{HCl} \text {. }\end{array}$ \\
\hline
\end{tabular}

"Grain size based on the Wentworth classification system (Wentworth, 1922). Proportions defined using the following terms: "trace" (0-10 percent), "little"

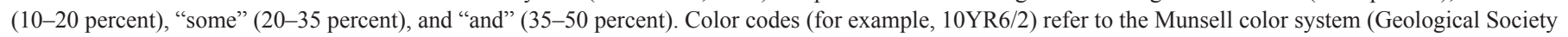
of America, 1995).

\section{LGRB Poly 26}

Date well completed: 10/25/2012

\section{Log prepared by L.R. Arnold}

[Depth intervals in feet below land surface; mm, millimeters; ft, feet; HCl, hydrochloric acid, LGRB, lower Gunnison River Basin; Poly, polygon number]

\begin{tabular}{|c|c|c|}
\hline Depth & Sample type & Description $^{1}$ \\
\hline $0-14.5$ & surface and core & $\begin{array}{l}\text { Alluvium-Clay, moderate yellowish brown }(10 \mathrm{YR} 5 / 4) \text { to dark yellowish brown }(10 \mathrm{YR} 4 / 2) \text {, } \\
\text { some very fine-fine sand with trace medium-coarse sand, soft, dry-damp, becoming wet } \\
\text { below } 14 \mathrm{ft} \text {, trace calcium carbonate mottling, trace organic matter and carbon specks } 0-9.5 \mathrm{ft} \text {, } \\
\text { reacts to } \mathrm{HCl} \text {. }\end{array}$ \\
\hline $14.5-19.7$ & core & $\begin{array}{l}\text { Alluvium-Sand, pale yellowish brown (10YR6/2) to moderate yellowish brown (10YR5/4), } \\
\text { fine-coarse grained, some clay, some gravel up to } 50 \mathrm{~mm} \text { diameter, poorly sorted, loose, } \\
\text { saturated. }\end{array}$ \\
\hline $19.7-20.6$ & core & $\begin{array}{l}\text { Alluvium-Gravel, pale yellowish brown (10YR6/2), up to } 40 \mathrm{~mm} \text { diameter, some clay, some } \\
\text { fine-very coarse sand, poorly sorted, angular-subangular, loose-medium dense, saturated. }\end{array}$ \\
\hline $20.6-24.5$ & core & $\begin{array}{l}\text { Weathered Mancos Shale - Clay, mottled dusky yellow (5Y6/4) to light olive gray }(5 \mathrm{Y} 5 / 2) \text {, } \\
\text { becoming olive gray ( } 5 \mathrm{Y} 3 / 2) \text { with depth, trace very fine sand, fissile, very stiff-hard, damp- } \\
\text { moist, trace small gypsum crystals and iron staining, reacts to } \mathrm{HCl} \text {. }\end{array}$ \\
\hline
\end{tabular}

'Grain size based on the Wentworth classification system (Wentworth, 1922). Proportions defined using the following terms: "trace" (0-10 percent), "little" (10-20 percent), "some" (20-35 percent), and "and" (35-50 percent). Color codes (for example, 10YR6/2) refer to the Munsell color system (Geological Society of America, 1995). 


\section{LGRB Poly 28}

Date well completed: 10/25/2012

\section{Log prepared by L.R. Arnold}

[Depth intervals in feet below land surface; ft, feet; $\mathrm{HCl}$, hydrochloric acid, LGRB, lower Gunnison River Basin; Poly, polygon number]

\begin{tabular}{|c|c|c|}
\hline Depth & Sample type & Description ${ }^{1}$ \\
\hline $0-3$ & surface and cuttings & $\begin{array}{l}\text { Alluvium-Clay, pale yellowish brown }(10 \mathrm{YR} 6 / 2) \text { to pale brown }(5 \mathrm{YR} 5 / 2) \text {, some very fine sand } \\
\text { and trace fine-medium sand, soft, dry-damp, some organic matter, reacts to } \mathrm{HCl} \text {. }\end{array}$ \\
\hline
\end{tabular}

${ }^{1}$ Grain size based on the Wentworth classification system (Wentworth, 1922). Proportions defined using the following terms: "trace" (0-10 percent), "little"

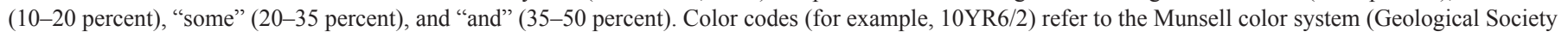
of America, 1995). 


\section{Appendix 2. Well-Construction Diagrams}

[LGRB, lower Gunnison River Basin; Poly, polygon number; PVC, polyvinyl chloride; ft, feet; in., inch; diam., diameter; Sch.40, Schedule 40] 


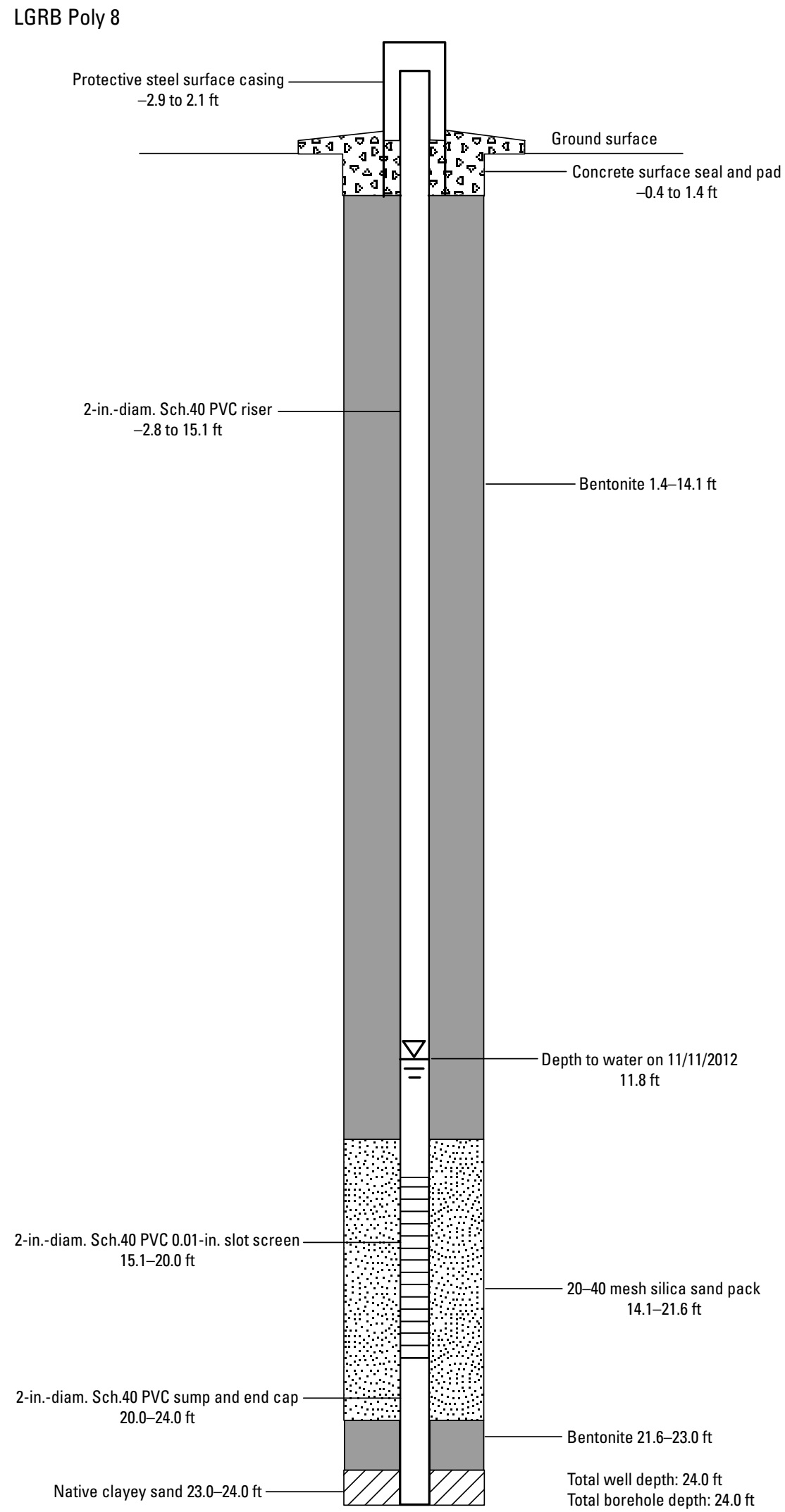




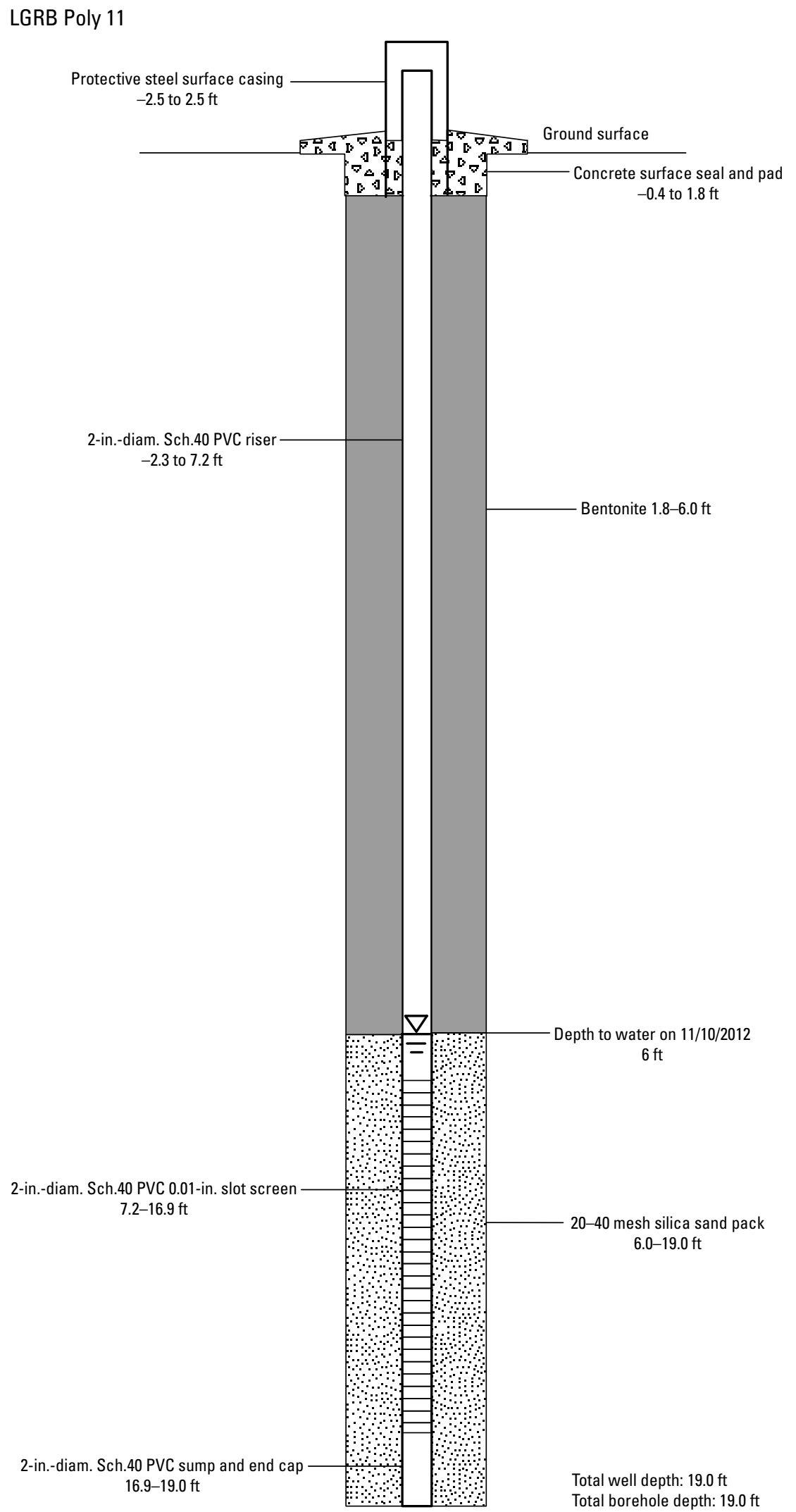


LGRB Poly 12

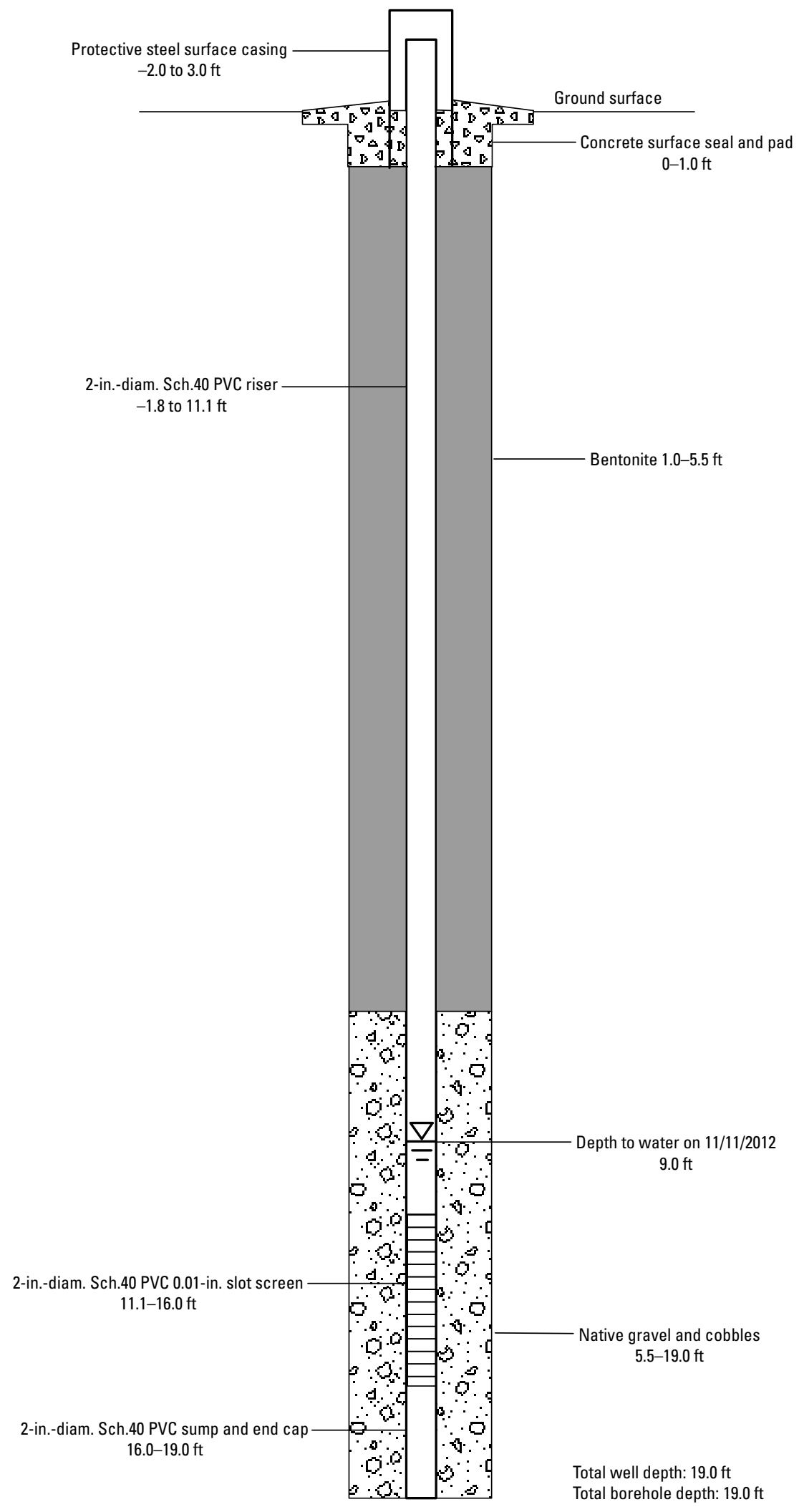


LGRB Poly 13

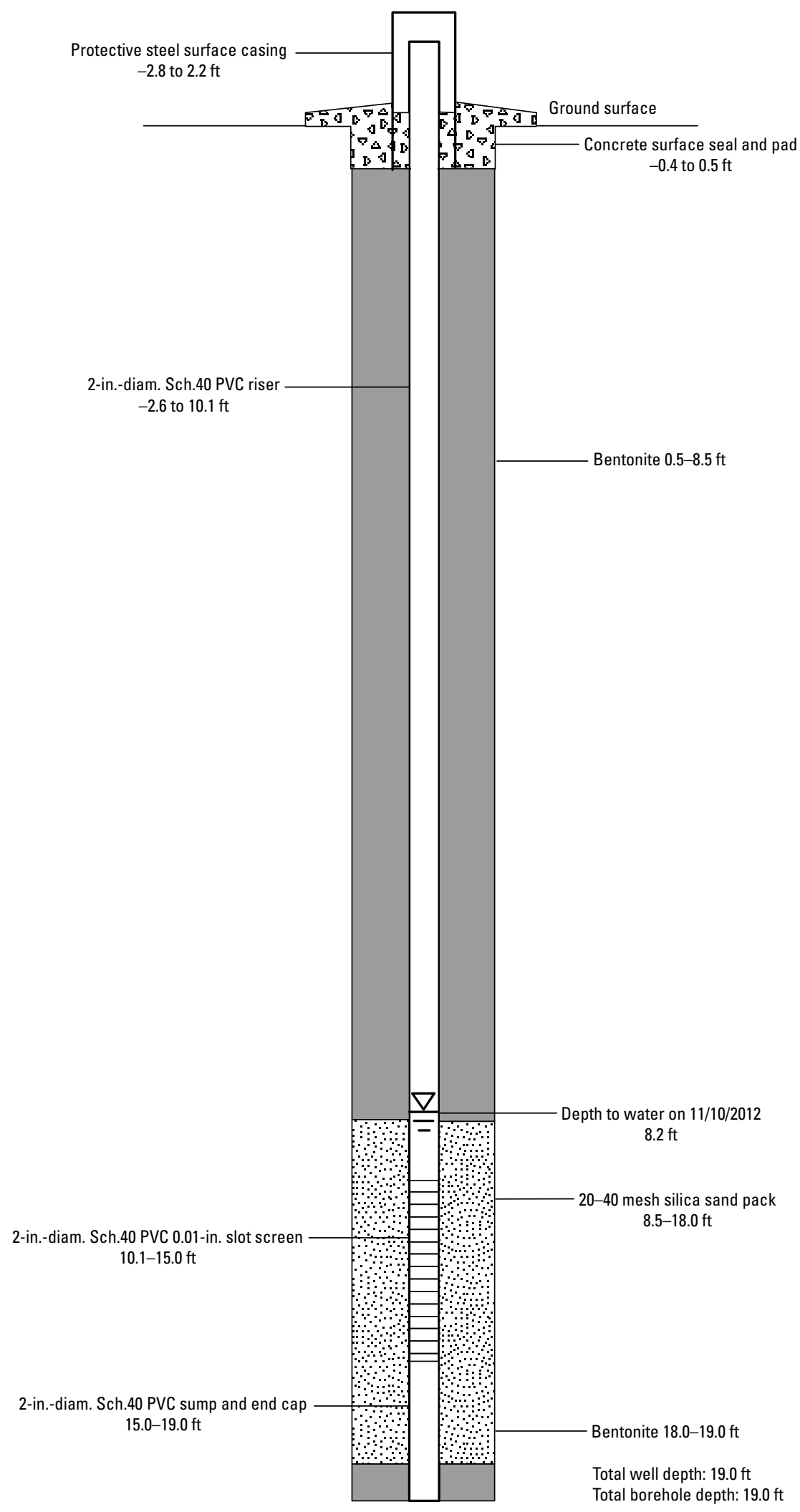


LGRB Poly 15

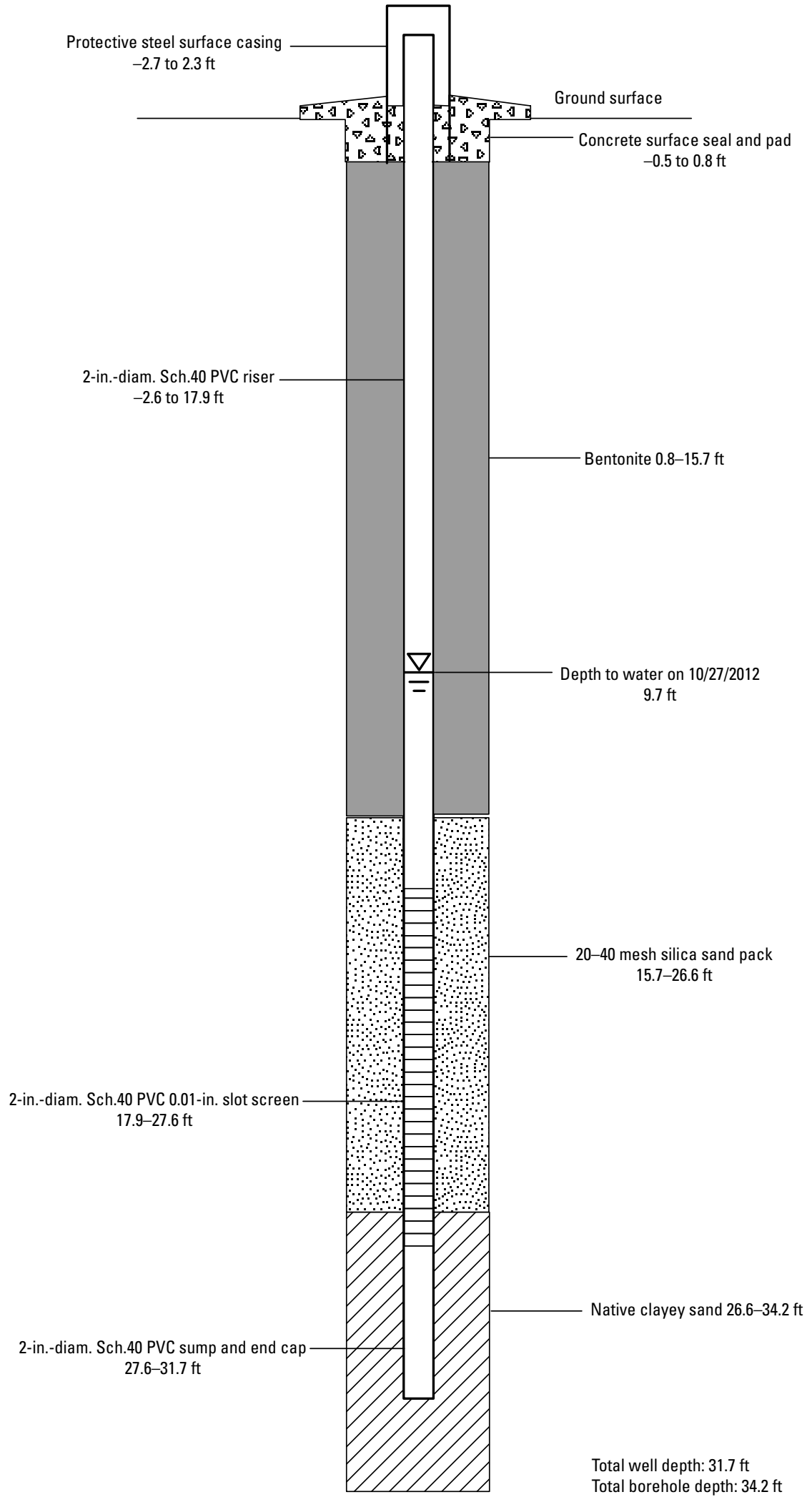




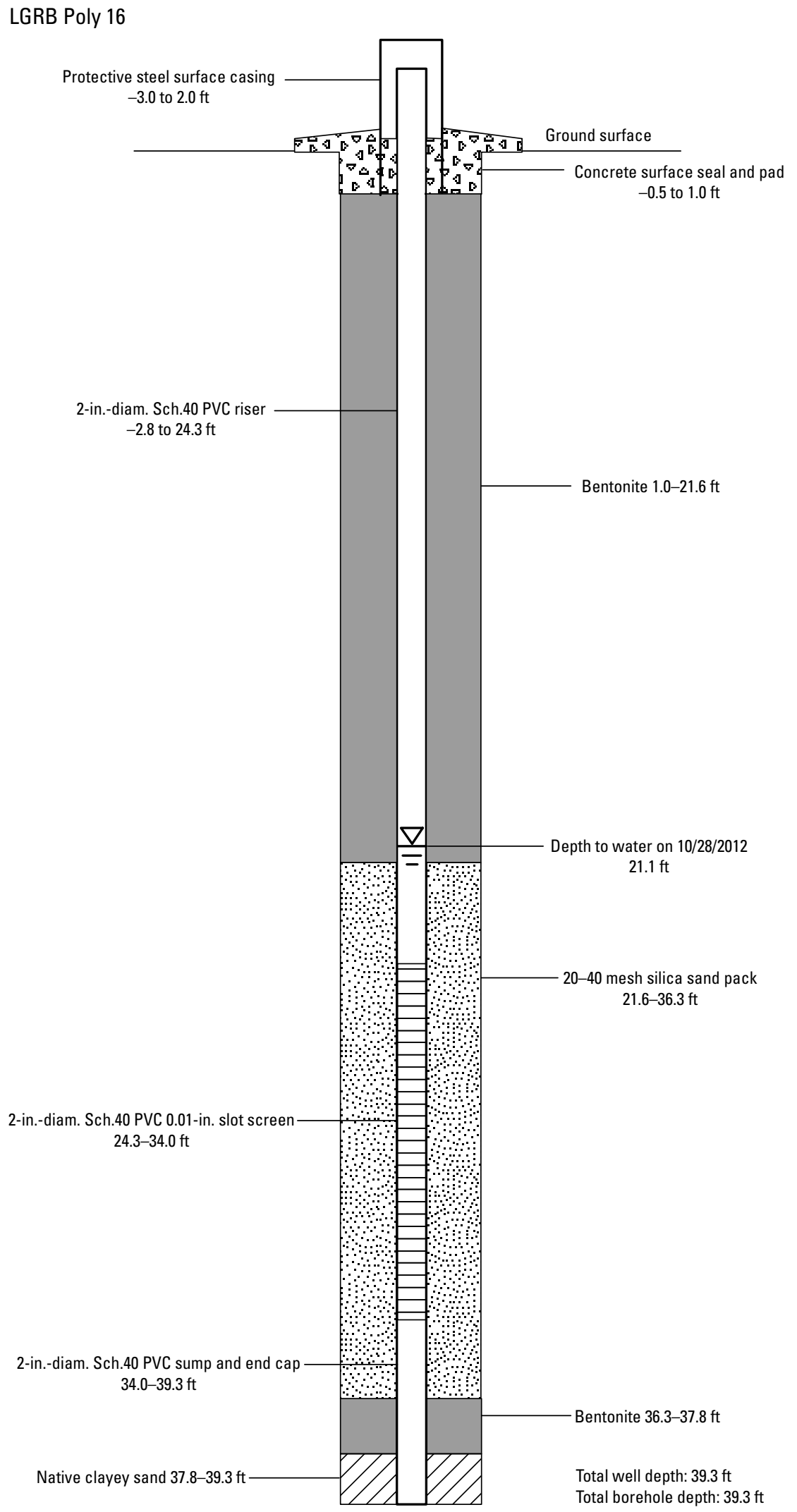


LGRB Poly 20

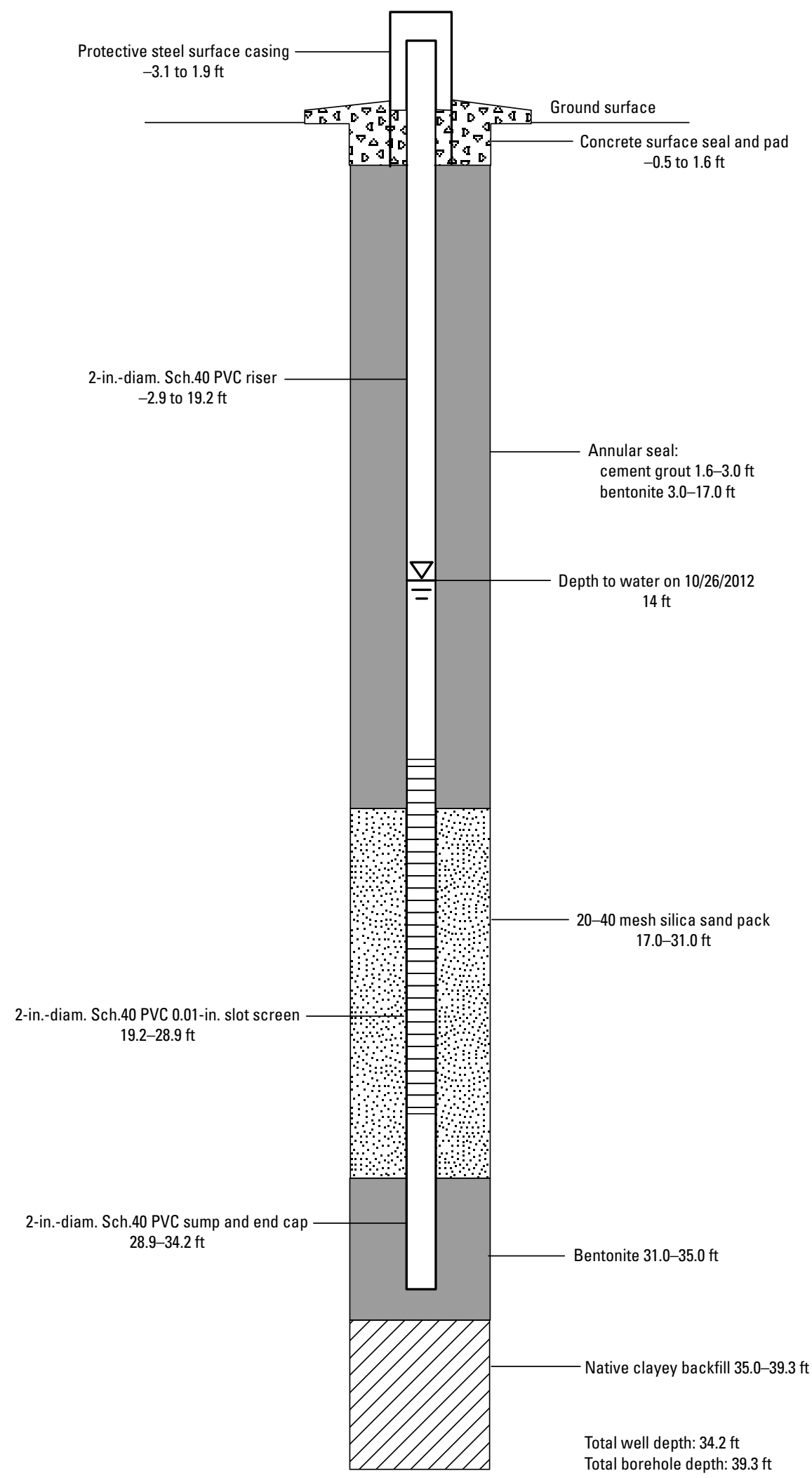


LGRB Poly 24

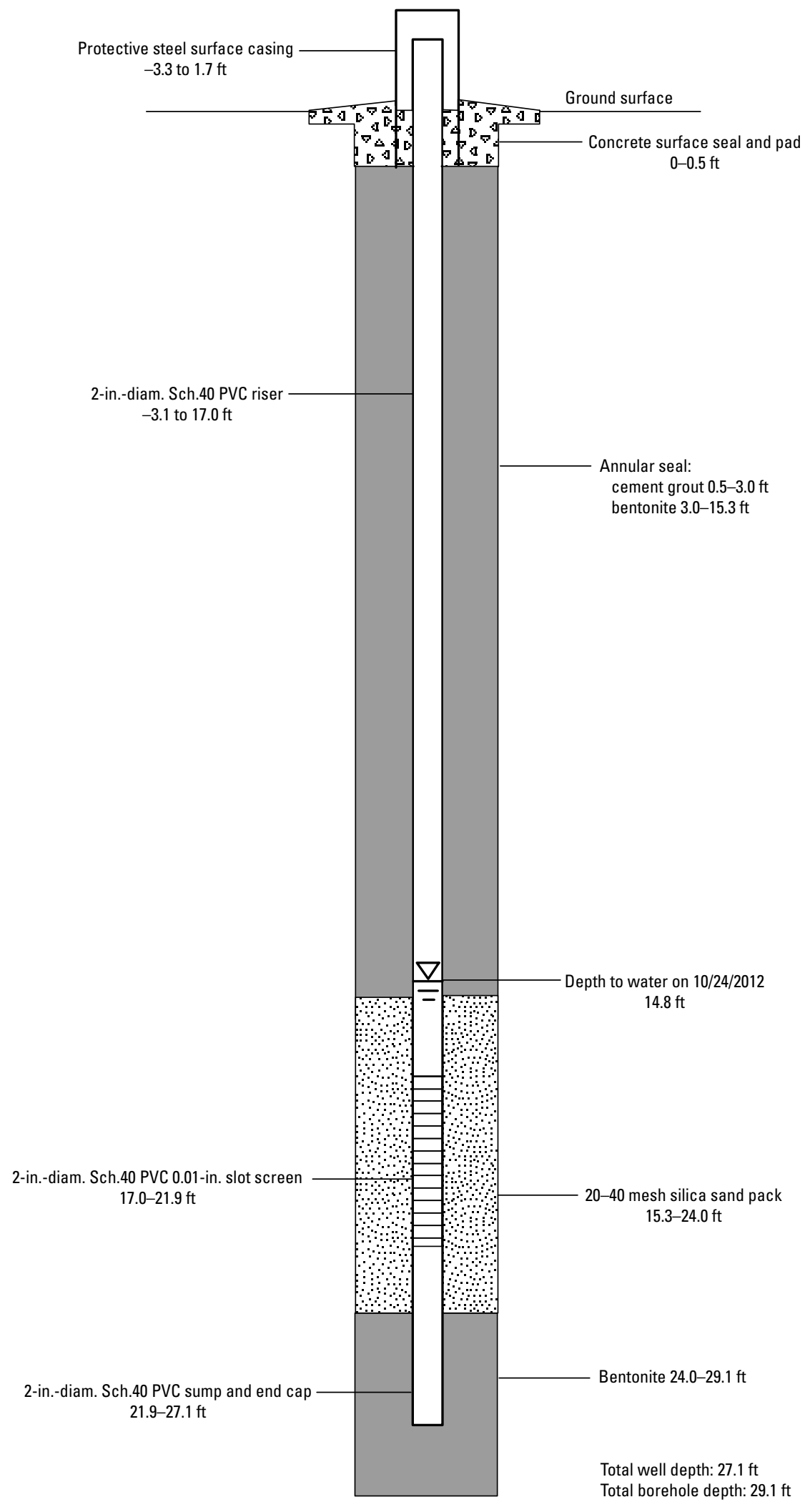


LGRB Poly 26

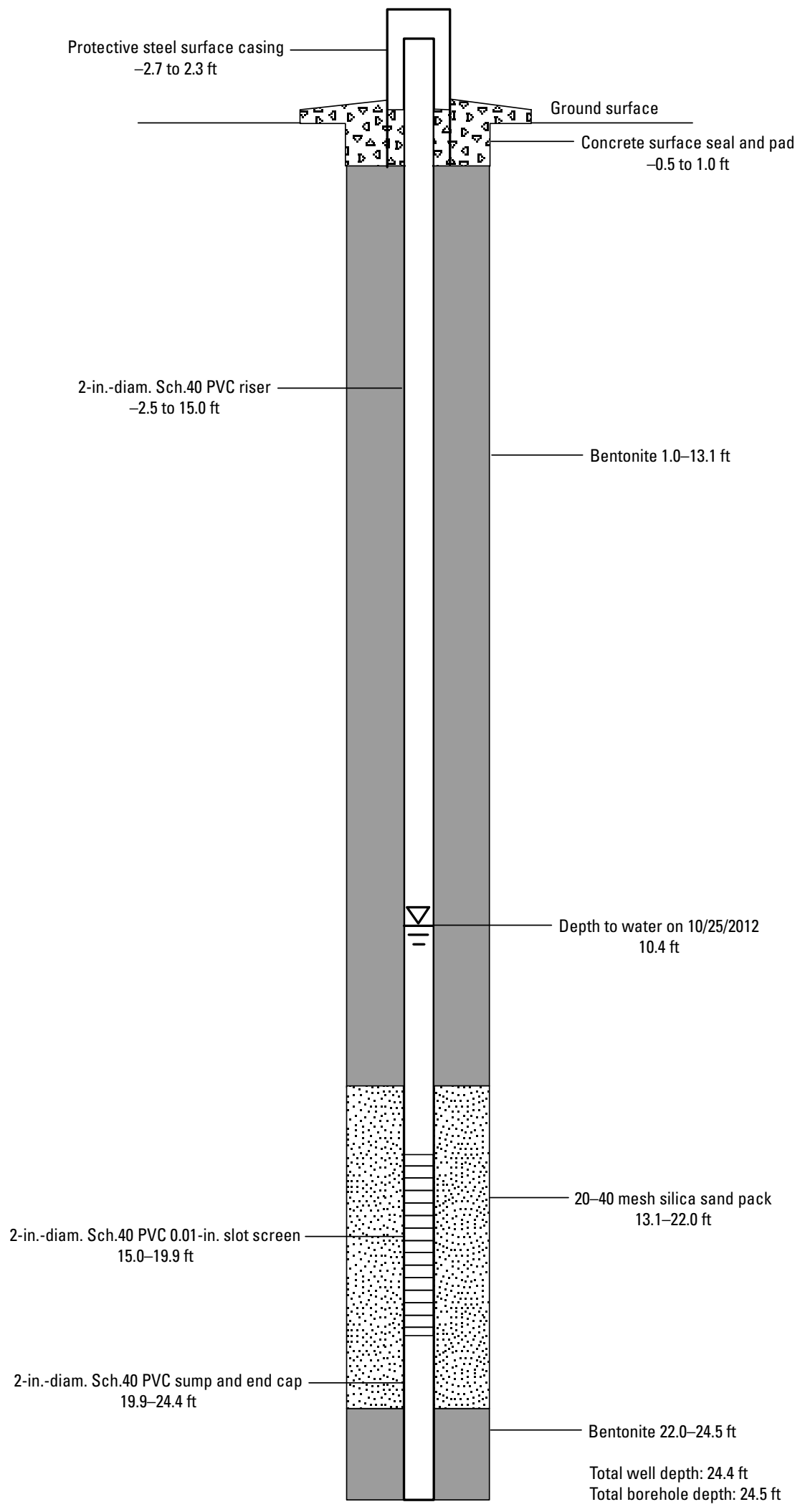


LGRB Poly 28

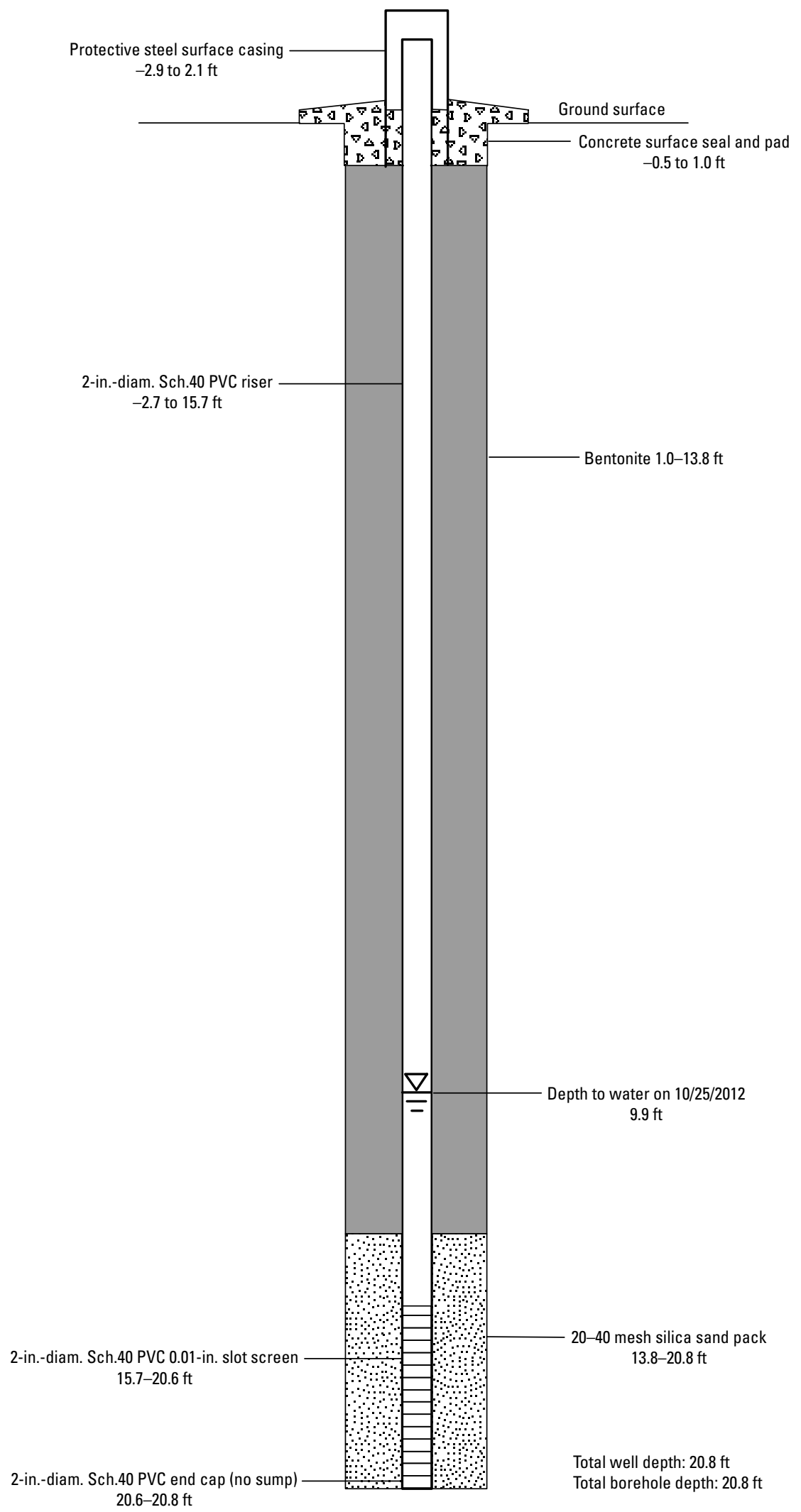




\section{Appendix 3. Well-Development Records}

\section{LGRB Poly 8}

\section{Date developed: 5/13/2013}

[gal/min, gallons per minute; ${ }^{\circ} \mathrm{C}$, degrees Celsius; $\mu \mathrm{S} / \mathrm{cm}$, microsiemens per centimeter; NTU, nephelometric turbidity units; >, greater than; - , no data; LGRB, lower Gunnison River Basin; Poly, polygon number]

\begin{tabular}{cccccl}
\hline $\begin{array}{c}\text { Pumping duration } \\
(\text { minutes) }\end{array}$ & $\begin{array}{c}\text { Temperature } \\
\left({ }^{\circ} \mathbf{C}\right)\end{array}$ & $\begin{array}{c}\text { Specific conductance } \\
(\boldsymbol{\mu} \mathbf{S} / \mathbf{c m})\end{array}$ & $\begin{array}{c}\text { Turbidity } \\
(\mathbf{N T U})\end{array}$ & $\begin{array}{c}\text { Pumping rate } \\
\text { (gal/min) }\end{array}$ & Appearance \\
\hline 0 & & & & & \\
50 & 13.9 & 10,660 & $>1,000$ & 0.5 & Muddy \\
65 & 13.3 & 10,920 & $>1,000$ & 0.5 & Slightly muddy \\
80 & 12.8 & 11,030 & 437 & - & Murky \\
95 & 12.5 & 11,100 & 228 & 0.8 & Murky \\
110 & 12.7 & 11,050 & 300 & 0.5 & Murky \\
125 & 13.8 & 10,980 & 235 & 0.5 & Murky \\
140 & 13.7 & 11,020 & 162 & - & Slightly murky \\
155 & 13.3 & 11,110 & 116 & 0.7 & Slightly murky \\
170 & 13.1 & 11,130 & 69 & - & Mostly clear \\
185 & 13.6 & 11,120 & 43 & - & Mostly clear \\
\hline
\end{tabular}

\section{LGRB Poly 11}

\section{Date developed: 5/16/2013}

[gal/min, gallons per minute; ${ }^{\circ} \mathrm{C}$, degrees Celsius; $\mu \mathrm{S} / \mathrm{cm}$, microsiemens per centimeter; NTU, nephelometric turbidity units; >, greater than; - , no data; LGRB, lower Gunnison River Basin; Poly, polygon number]

\begin{tabular}{|c|c|c|c|c|c|}
\hline $\begin{array}{l}\text { Pumping duration } \\
\text { (minutes) }\end{array}$ & $\begin{array}{l}\text { Temperature } \\
\left({ }^{\circ} \mathrm{C}\right)\end{array}$ & $\begin{array}{l}\text { Specific conductance } \\
(\mu \mathrm{S} / \mathrm{cm})\end{array}$ & $\begin{array}{c}\text { Turbidity } \\
\text { (NTU) }\end{array}$ & $\begin{array}{l}\text { Pumping rate } \\
\text { (gal/min) }\end{array}$ & Appearance \\
\hline 0 & - & - & - & pump on & - \\
\hline 70 & - & - & - & - & - \\
\hline 75 & 12.5 & 3,250 & - & 0.5 & Muddy \\
\hline 120 & 12.6 & 3,240 & $>1,000$ & 0.4 & Slightly muddy \\
\hline 150 & 11.9 & 3,230 & 930 & 0.5 & Murky \\
\hline 180 & 12.2 & 3,240 & $>1,000$ & 0.5 & Murky \\
\hline 210 & 12.7 & 3,200 & 412 & 0.5 & Murky \\
\hline 225 & 12.2 & 3,230 & 61 & - & Mostly clear \\
\hline 240 & 12.2 & 3,250 & 16 & 0.4 & Clear \\
\hline
\end{tabular}




\section{LGRB Poly 12}

\section{Date developed: 5/15/2013 through 5/17/2013}

[gal/min, gallons per minute; ${ }^{\circ} \mathrm{C}$, degrees Celsius; $\mu \mathrm{S} / \mathrm{cm}$, microsiemens per centimeter; NTU, nephelometric turbidity units; >, greater than; \pm , plus or minus; —, no data; gal, gallons; LGRB, lower Gunnison River Basin; Poly, polygon number]

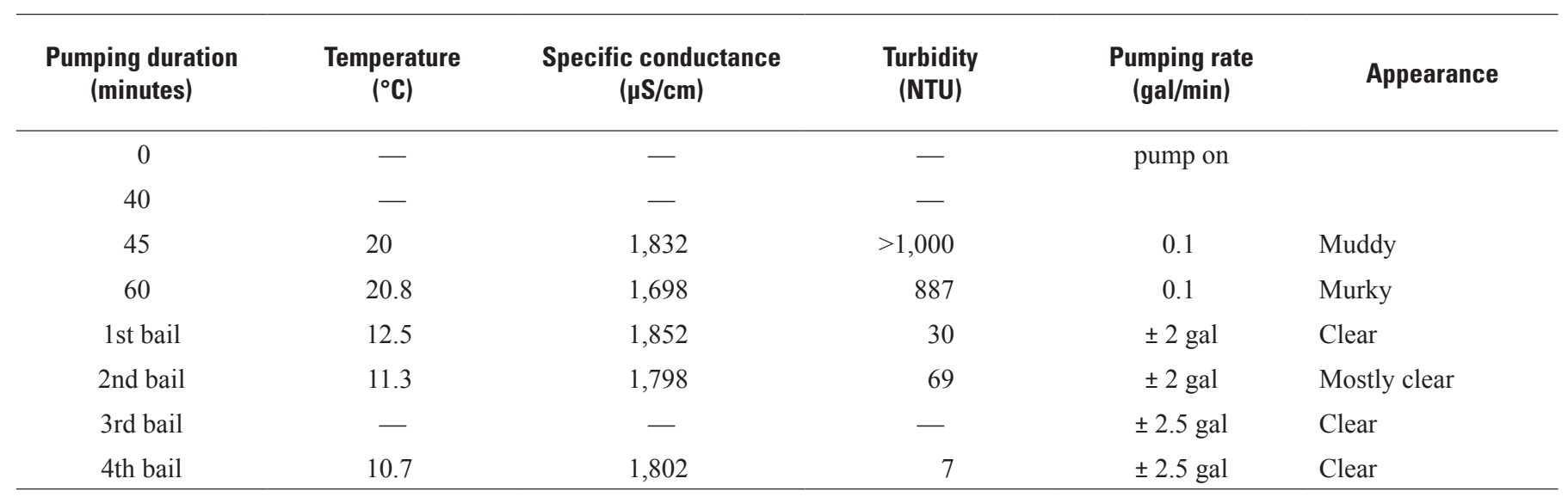

Comments: Poor producer, pumped dry in 75 minutes, recover rate of 0.2 feet per minute. Allowed to recover to 9.1 feet below land surface and started bailing, 7 gallons removed. 1st and 2nd bails on 5/15/2013 at 1235 and 1805 respectively. 3rd bail on 5/16/2013. 4th bail on 5/17/2013.

\section{LGRB Poly 13}

Date developed: 5/15/2013

[gal/min, gallons per minute; ${ }^{\circ} \mathrm{C}$, degrees Celsius; $\mu \mathrm{S} / \mathrm{cm}$, microsiemens per centimeter; NTU, nephelometric turbidity units; >, greater than; - , no data; LGRB, lower Gunnison River Basin; Poly, polygon number]

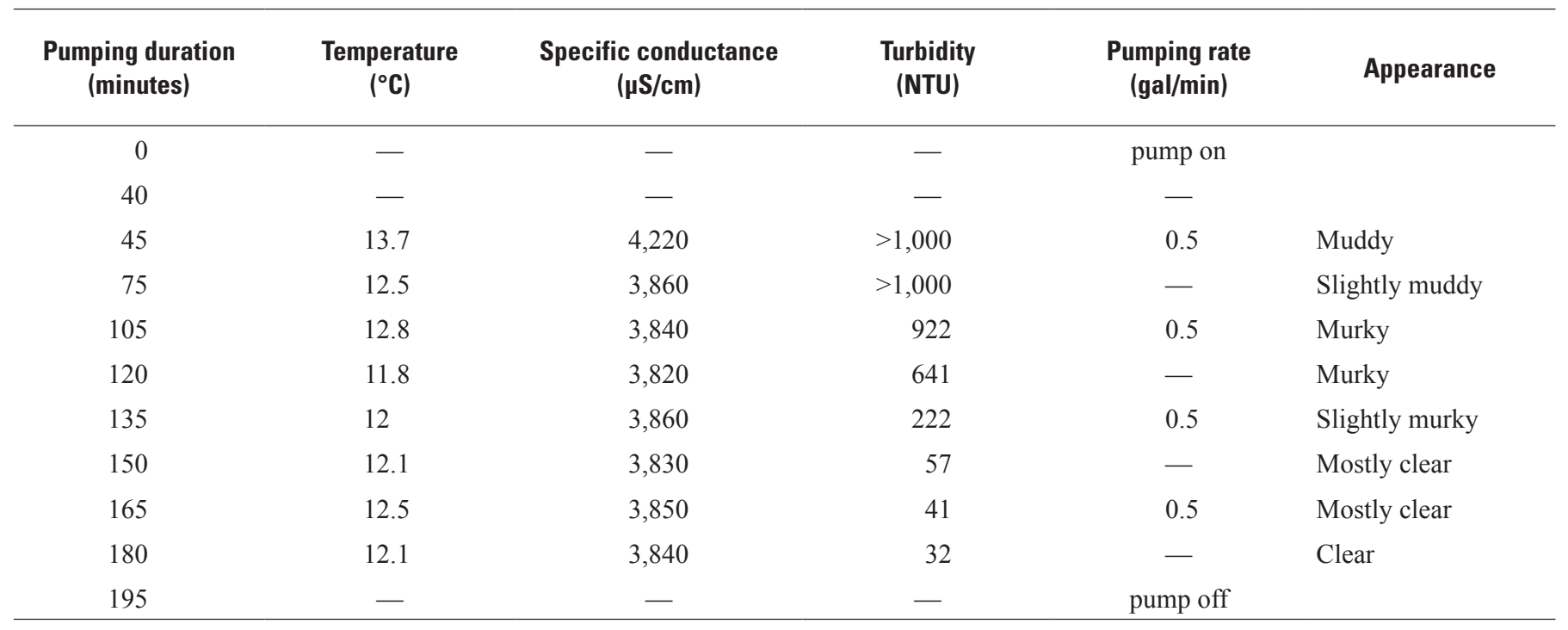




\section{LGRB Poly 15}

\section{Date developed: 5/17/2013}

[gal/min, gallons per minute; ${ }^{\circ} \mathrm{C}$, degrees Celsius; $\mu \mathrm{S} / \mathrm{cm}$, microsiemens per centimeter; NTU, nephelometric turbidity units; >, greater than; <, less than; —, no data; LGRB, lower Gunnison River Basin; Poly, polygon number]

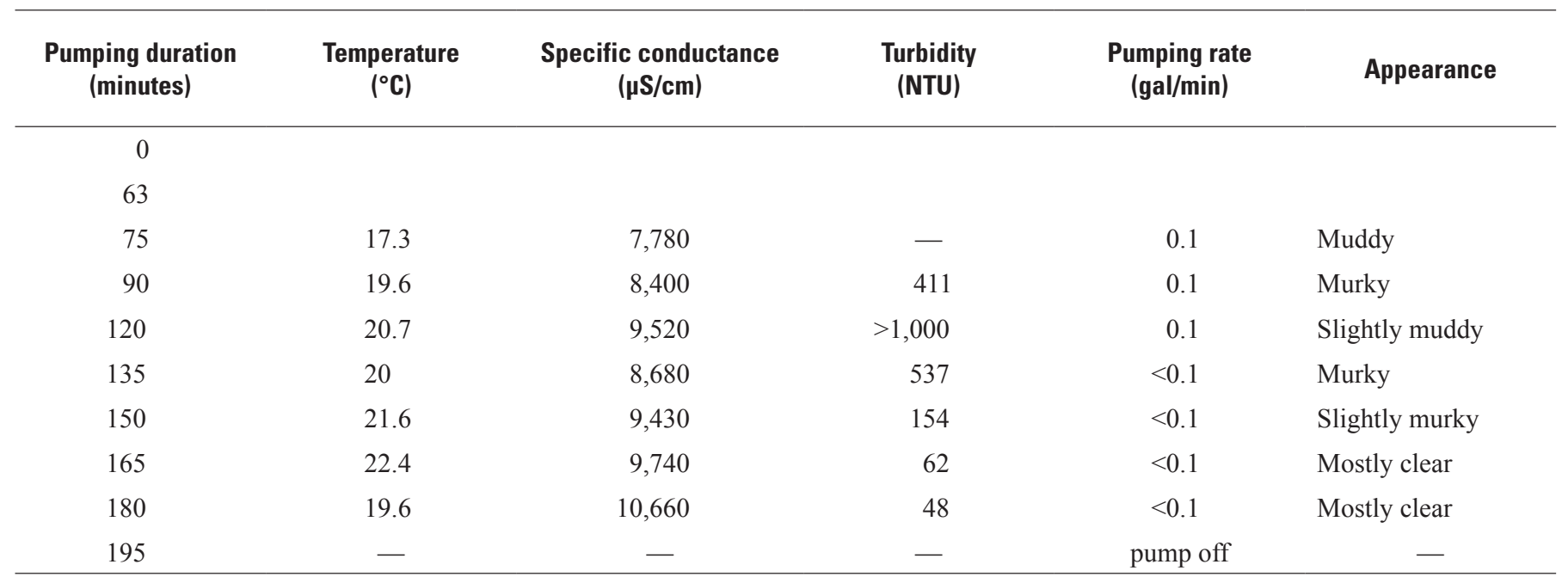

\section{LGRB Poly 16}

\section{Date developed: 5/16/2013}

[gal/min, gallons per minute; ${ }^{\circ} \mathrm{C}$, degrees Celsius; $\mu \mathrm{S} / \mathrm{cm}$, microsiemens per centimeter; NTU, nephelometric turbidity units; >, greater than; -, no data; LGRB, lower Gunnison River Basin; Poly, polygon number]

\begin{tabular}{cccccc}
\hline $\begin{array}{c}\text { Pumping duration } \\
\text { (minutes) }\end{array}$ & $\begin{array}{c}\text { Temperature } \\
\left({ }^{\circ} \mathbf{C}\right)\end{array}$ & $\begin{array}{c}\text { Specific conductance } \\
(\boldsymbol{\mu S} / \mathbf{c m})\end{array}$ & $\begin{array}{c}\text { Turbidity } \\
\text { (NTU) }\end{array}$ & $\begin{array}{c}\text { Pumping rate } \\
\text { (gal/min) }\end{array}$ & Appearance \\
\hline 0 & & & & & \\
48 & 13 & 4,180 & off scale & 0.6 & Muddy \\
60 & 12.9 & 4,210 & $>1,000$ & 0.7 & Slightly muddy \\
90 & 12.7 & 4,220 & $>1,000$ & 1 & Slightly muddy \\
120 & 13.5 & 4,220 & $>1,000$ & 0.5 & Slightly muddy \\
150 & 15 & 4,210 & $>1,000$ & 0.4 & Slightly muddy \\
180 & 12.9 & 4,220 & 426 & 0.8 & Murky \\
240 & 13.4 & 4,220 & 258 & 0.4 & Murky \\
270 & 13.3 & 4,230 & 262 & 0.5 & Murky \\
300 & 13.8 & 4,220 & 222 & - & Slightly murky \\
330 & 14.3 & 4,210 & 229 & 0.4 & Slightly murky \\
\hline
\end{tabular}




\section{LGRB Poly 20}

\section{Date developed: 5/15/2013 and 5/17/2013}

[gal/min, gallons per minute; ${ }^{\circ} \mathrm{C}$, degrees Celsius; $\mu \mathrm{S} / \mathrm{cm}$, microsiemens per centimeter; NTU, nephelometric turbidity units; >, greater than; \pm , plus or minus; -, no data; gal, gallons; LGRB, lower Gunnison River Basin; Poly, polygon number]

\begin{tabular}{|c|c|c|c|c|c|}
\hline \multicolumn{6}{|l|}{70} \\
\hline 75 & 15.4 & 14,410 & $>1,000$ & 0.5 & Muddy \\
\hline 1st bail & 14.6 & 18,500 & 27 & $\pm 5 \mathrm{gal}$ & Murky \\
\hline 2nd bail & 12.3 & 18,560 & 18 & $\pm 10 \mathrm{gal}$ & Clear yellow \\
\hline
\end{tabular}

Comments: Bailed well dry on 5/15/2013 (1st bail); bailed well dry on 5/17/2013 (2nd bail).

\section{LGRB Poly 24}

\section{Date developed: 5/14/2013 and 5/17/2013}

[gal/min, gallons per minute; ${ }^{\circ} \mathrm{C}$, degrees Celsius; $\mu \mathrm{S} / \mathrm{cm}$, microsiemens per centimeter; NTU, nephelometric turbidity units; >, greater than; - , no data; LGRB, lower Gunnison River Basin; Poly, polygon number]

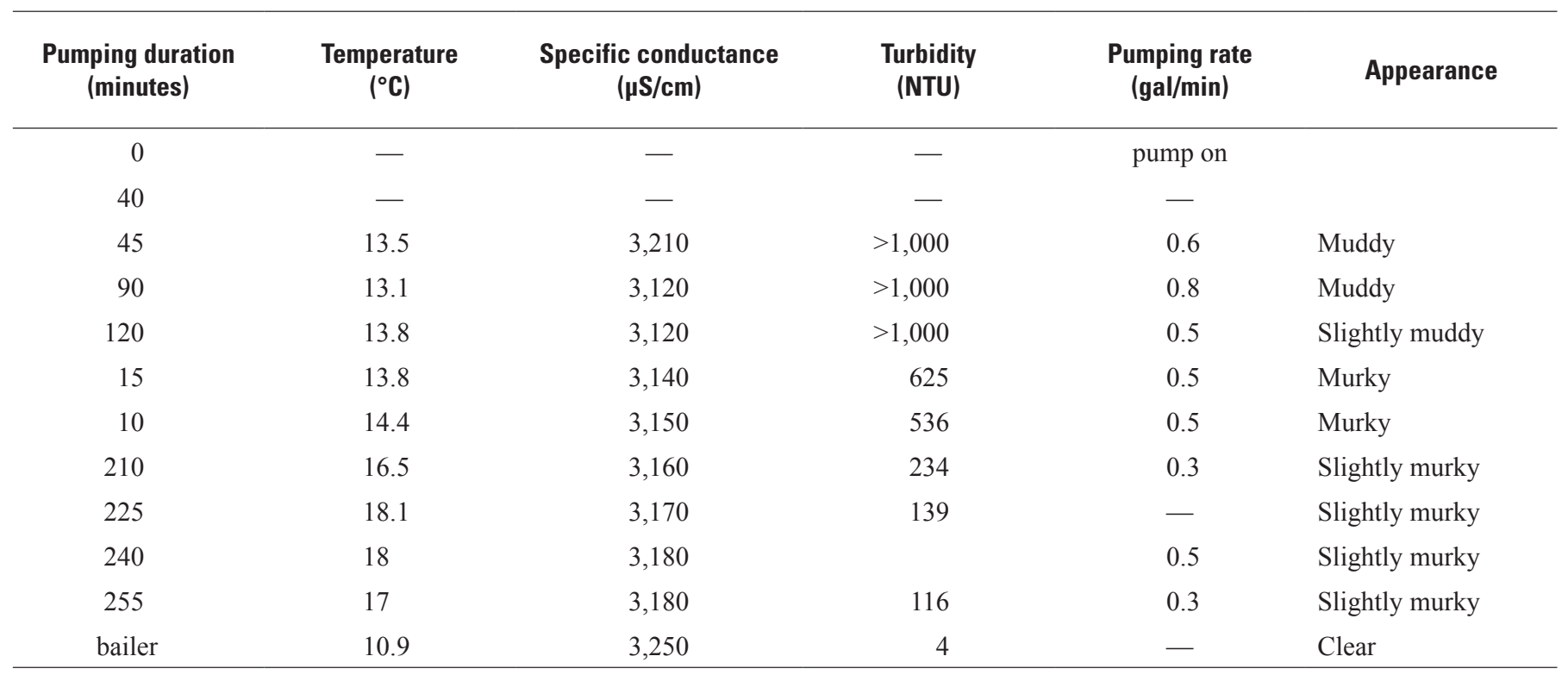




\section{LGRB Poly 26}

\section{Date developed: 5/14/2013}

[gal/min, gallons per minute; ${ }^{\circ} \mathrm{C}$, degrees Celsius; $\mu \mathrm{S} / \mathrm{cm}$, microsiemens per centimeter; NTU, nephelometric turbidity units; >, greater than; - , no data; LGRB, lower Gunnison River Basin; Poly, polygon number]

\begin{tabular}{cccccc}
\hline $\begin{array}{c}\text { Pumping duration } \\
\text { (minutes) }\end{array}$ & $\begin{array}{c}\text { Temperature } \\
\left({ }^{\circ} \mathbf{C}\right)\end{array}$ & $\begin{array}{c}\text { Specific conductance } \\
(\boldsymbol{\mu S} \mathbf{S} \mathbf{c m})\end{array}$ & $\begin{array}{c}\text { Turbidity } \\
\text { (NTU) }\end{array}$ & $\begin{array}{c}\text { Pumping rate } \\
(\mathbf{g a l} / \mathbf{m i n})\end{array}$ & Appearance \\
\hline 0 & - & - & - & pump on & \\
40 & & & - & \\
45 & 12.3 & 5,560 & $>1,000$ & 0.8 & Muddy \\
60 & 12.4 & 5,530 & 177 & 0.8 & Slightly murky \\
75 & 12.1 & 5,520 & 114 & - & Slightly murky \\
90 & 12 & 5,520 & 62 & 0.8 & Mostly clear \\
105 & 11.4 & 5,510 & 40 & - & Mostly clear \\
120 & 11 & 5,500 & 25 & 0.8 & Clear \\
\hline
\end{tabular}

\section{LGRB Poly 28}

\section{Date developed: 5/14/2013}

[gal/min, gallons per minute; ${ }^{\circ} \mathrm{C}$, degrees Celsius; $\mu \mathrm{S} / \mathrm{cm}$, microsiemens per centimeter; NTU, nephelometric turbidity units; >, greater than; - , no data; LGRB, lower Gunnison River Basin; Poly, polygon number]

\begin{tabular}{cccccc}
\hline $\begin{array}{c}\text { Pumping duration } \\
\text { (minutes) }\end{array}$ & $\begin{array}{c}\text { Temperature } \\
\left({ }^{\circ} \mathbf{C}\right)\end{array}$ & $\begin{array}{c}\text { Specific conductance } \\
(\boldsymbol{\mu S} / \mathbf{c m})\end{array}$ & $\begin{array}{c}\text { Turbidity } \\
\text { (NTU) }\end{array}$ & $\begin{array}{c}\text { Pumping rate } \\
\text { (gal/min) }\end{array}$ & Appearance \\
\hline 0 & - & - & - & pump on & \\
40 & - & 4,320 & $>1,000$ & & \\
45 & 13.7 & 590 & 0.4 & Muddy \\
60 & 12.2 & 4,320 & 320 & - & Murky \\
75 & 12.3 & 4,310 & 214 & 0.5 & Slightly murky \\
90 & 12.3 & 4,300 & 142 & - & Slightly murky \\
105 & 12.4 & 4,300 & 88 & 0.5 & Mostly clear \\
120 & 12.2 & 4,310 & 68 & - & Mostly clear \\
135 & 12.2 & 4,300 & 35 & 0.5 & Clear \\
\hline
\end{tabular}


